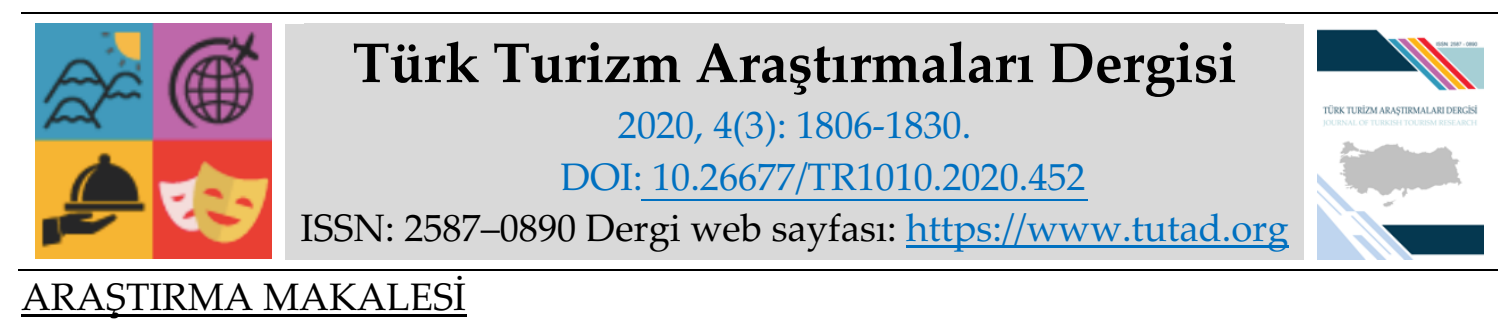

\title{
Ön Büro ve Yiyecek-İçecek Personelinin Sabır Düzeylerinin Belirlenmesi
}

Doç. Dr. Atınç OLCAY, Gaziantep Üniversitesi, Turizm ve Otelcilik Meslek Yüksek Okulu, Gaziantep, e-posta: olcay@gantep.edu.tr

ORCID: https://orcid.org/0000-0003-0407-5467

Burçin ÖZKAN, Yüksek Lisans Öğrencisi, Gaziantep Üniversitesi, Sosyal Bilimler Enstitüsü, Gaziantep, e-posta: burcinozkan92@gmail.com

ORCID: https://orcid.org/0000-0002-1371-2512

Ahmet CUMA, Yüksek Lisans Öğrencisi, Gaziantep Üniversitesi, Sosyal Bilimler Enstitüsü, Gaziantep, e-posta: ahmetcuma7@gmail.com

ORCID: https://orcid.org/0000-0002-2676-977X

Öz

Bu çalışmada Kahramanmaraş ilinde faaliyet gösteren turizm belgeli otel işletmelerinde istihdam edilen ön büro ve servis personellerinin sabır düzeylerinin belirlenmesi ile sabır düzeylerinin demografik ve mesleki değişkenlere göre farklılık gösterip göstermediğinin incelenmesi amaçlanmıştır. Çalışmanın örneklemini 2019 yılının Şubat ve Mart aylarında Kahramanmaraş ilinde faaliyet gösteren turizm belgeli otel işletmelerinde çalışan 182 ön büro ve servis personeli oluşturmaktadır. Araştırmanın verileri anket yöntemi ile toplanmıştır. Elde edilen veriler betimleyici istatistik teknikleri, Mann Whitney U Testi ve Kruskal Wallis Testi ile analiz edilmiştir. Araştırma sonucunda ön büro ve servis personellerinin sabır düzeylerinin ağırlıklı olarak yüksek olduğu ve sabır düzeyinin medeni durum ve sektör tecrübesine göre farklılık gösterdiği fakat cinsiyet, yaş, eğitim durumu ve bölüme göre farklılık göstermediği tespit edilmiştir. Elde edilen sonuçlar literatür kapsamında tartışılmış ve birtakım öneriler sunulmuştur.

Anahtar Kelimeler: Sabır, Turizmde Sabır, Ön Büro, Yiyecek-İçecek, Kahramanmaraş.

Makale Gönderme Tarihi: 14.02 .2020

Makale Kabul Tarihi: 03.07.2020

Önerilen Atıf:

Olcay, A., Özkan, B. ve Cuma, A. (2020). Ön Büro ve Yiyecek-İçecek Personelinin Sabır Düzeylerinin Belirlenmesi, Türk Turizm Araştırmaları Dergisi, 4(3): 1806-1830.

(C) 2020 Türk Turizm Araştırmaları Dergisi. 


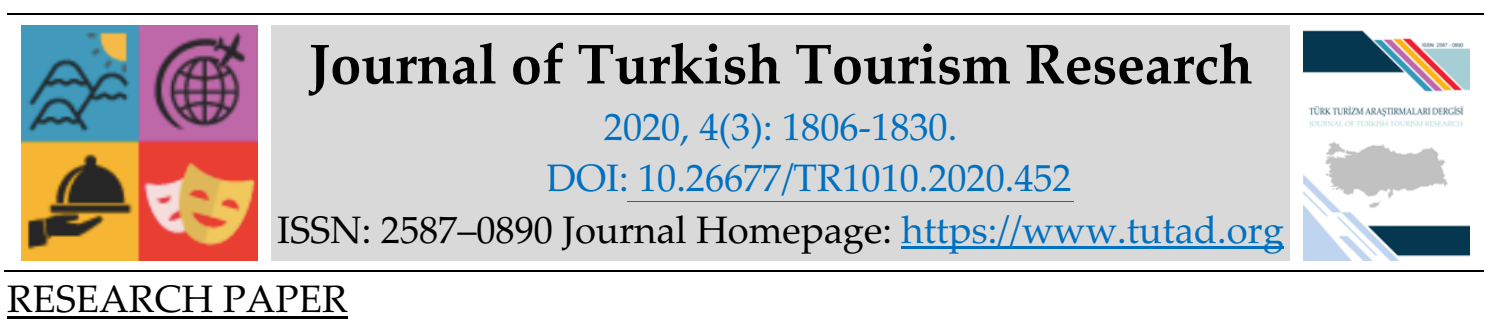

\title{
Determination of Patience Levels of Front Office and Food and Beverage Staff
}

Associate Prof. Dr. Atınç OLCAY, Gaziantep University, School of Tourism and Hotel Management, Gaziantep, e-mail: olcay@gantep.edu.tr ORCID: https://orcid.org/0000-0003-0407-5467

Burçin ÖZKAN, MSc. Student, Gaziantep University, Social Sciences Institute, Gaziantep, e-mail: burcinozkan92@gmail.com ORCID: https://orcid.org/0000-0002-1371-2512

Ahmet CUMA, MSc. Student, Gaziantep University, Social Sciences Institute, Gaziantep, e-mail: ahmetcuma7@gmail.com

ORCID: https://orcid.org/0000-0002-2676-977X

\begin{abstract}
In this study, it was aimed to determine the patience levels of the front office and service personnel employed in the hotels with tourism certificates operating in the province of Kahramanmaraş and to examine whether the patience levels differ according to demographic and professional variables. The sample of the study consists of 182 front offices and service personnel working in hotel businesses with tourism certificates operating in Kahramanmaraş province in February and March 2019. The data of the research were collected by the survey method. The data obtained were analyzed with descriptive statistics techniques, Mann Whitney U Test and Kruskal Wallis Test. As a result of the research, it has been determined that the patience levels of the front desk and service personnel are predominantly high and the level of patience differs according to the marital status and sector experience, but not according to gender, age, education status and department. The obtained results are discussed within the scope of the literature and some suggestions are presented.
\end{abstract}

Keywords: Patience, Patience in Tourism, Front office, Food and beverage, Kahramanmaraş.

Received: 14.02 .2020

Accepted: 03.07.2020

Suggested Citation:

Olcay, A., Özkan, B. and Cuma, A. (2020). Determination of Patience Levels of Front Office and Food and Beverage Staff, Journal of Turkish Tourism Research, 4(3): 1806-1830.

(C) 2020 Türk Turizm Araştırmaları Dergisi. 


\section{Gíriş}

Son yıllarda teknolojinin gelişmesi ile birlikte insan hayatı bir yandan kolaylaşırken bir yandan da zorlaşmaktadır. Modern çağın getirmiş olduğu hız faktörü, bireylerin en küçük şeylere bile sabredememesine neden olmaktadır. Bunun gibi durumlar kişilerin sabır eğilimlerinde düşüş olduğunu göstermektedir. İstenilen her şeye kolayca ulaşılabilmesi insanlara sabrın ne olduğunu unutturmaktadır. Çoğu zaman en küçük olaylara bile sabır gösterilmediği için insanlar arasında kavgaya bile varabilen tartışmalar yaşanabilmektedir. Bireyler artık daha fazla psikolojik danışmana ihtiyaç duymaktadırlar. Modern çağın getirdiği koşullar sebebiyle fiziksel ve psikolojik rahatsızlıklar yaşayan insan sayısı artmaktadır. Korkular, adaletsizlikler, kazalar, terör vb. üzücü durumlarla başa çıkmada sabır önemli bir faktördür (Seyhan, 2015: 128).

Sabır kelimesi Arapça "sabera” kökünden Türkçe’ye sabır olarak geçmiştir. Sabır kelimesi günlük yaşamda veya uzun süreli olarak insanın hoşuna gitmeyecek durum ve olaylar karşısında dinginlik, sakinlik göstermesini ifade etmektedir. Schnitker (2012: 263)'e göre sabır "kişinin hayal kırıklı̆̆l, sıkıntı ve acılar karşısında sakin bir şekilde beklemesidir". Sabır kelimesi günlük hayatta sıklıkla kullanılmaktadır. Sabır halk arasında daha çok dayanma, katlanma, aldırmama, müsamaha gösterme ve tahammül etme gibi anlamlarda kullanılmaktadır. Bu yüzden insan hayatının her alanında ihtiyacı olan bir değer olarak açıklanmaktadır (Gül ve Çeliköz, 2018: 7778). Çünkü uzun süreli üzücü durumlarda değil günlük hayatta da sabırlı bir tutuma ihtiyaç duyulmaktadır. Sabır sadece olumsuz durumlarda değil, aynı zamanda insanların iyi şeyleri umut ettiği zaman da başvurdukları bir değerdir (Doğan, 2017: 135).

Küreselleşen dünyada kişilerarası iletişim daha da önemli bir hal almıştır. Çünkü düşünce, görüş ve kültür farklılıkları gibi birçok faktör nedeniyle kişilerarası iletişimde sorunların artması muhtemeldir. Bireyler, yoğun iş hayatında iş yükü ve insani ilişkilerinde çeşitli sıkıntı ve stres yaşamaktadırlar. Bu olumsuz durumlarla baş etmede sabırlı olmanın çok doğru bir tutum olduğu düşünülmektedir. Kur'an'da insan ilişkilerinde yıpranmamak için "Öyleyse sen, onların dediklerine karşıllı sabret ve Rabbini güneşin doğuşundan önce ve batışından önce hamd ile tesbih et" (Kâf, 50/39) buyrularak sabır tavsiye edilmiştir (Karakaş, 2016: 2743).

Özellikle son yıllarda insan hayatına giren hız faktörü bireylere sabrın ne olduğunu unutturmaktadır. Bu bağlamda hizmet sektörü gibi insan ilişkilerinin yoğun olduğu sektörlerde çalışan kişilerin sabırlı bir tutum sergilemesi gerek fizyolojik gerekse psikolojik açıdan önemlidir. Okçu ve Pilatin (2018: 103), sabırlı insanlarda daha az stres, düşük depresyon, daha az sağlık problemleri ve artan yaşam doyumu gözlendiğini belirtmiştir. Yapılan akademik araştırmaların sonucu, sabır tutumunun yaşam doyumu, psikolojik iyi oluş, özsaygı ve başa çıkma düzeyini arttıran bir faktör olduğuna işaret etmektedir (Schnitker, 2012; Gençdoğan, Gülbahçe ve Gülbahçe, 2015; Karakaş, 2016; Qodariah ve Puspitasari, 2016; Doğan, 2017; Koç ve Arslan, 2019; Türkgeldi, 2019). Turizm sektörü emek-yoğun ilişkisinin yoğun olduğu doğrudan istihdamın yaşandığı bir sektördür. Sektördeki ağır çalışma koşulları nedeniyle işgörenlerde tahammülsüzlükler ve öfkelenmeler görülebilmektedir. Turizm sektöründe çalışanlar söz konusu olumsuzluklardan oldukça etkilenmektedir. Bu durum turizm çalışanlarını sosyal, ekonomik ve psikolojik yönden olumsuz olarak etkilemektedir.

Araştırmada öncelikle turizm yazınında, sabır kavramı ile ilgili tarama yapılmıştır. Ulaşılabilen araştırmalarda sabır kavramına iletişim becerisi kapsamında veya turizm personelinde olması gereken özelliklerden biri olarak sınırlı şekilde değinildiği görülmüştür. Bazı araştırmacılar turizm sektöründe çalışan personel ile turizm-otelcilik mesleğini seçecek öğrencilerin sabırlı kişiler olması gerektiğini belirtmişlerdir (Tetik, 2006; Öztürk ve Pekduyurucu, 2009; Ünüvar, 2009; Demirtaş, 2010a; Demirtaş, 2010b; Pelit ve Öztürk, 2011; Kaya ve Özhan, 2012; Polat Üzümcü, 2015; Eker ve Zengin, 2016; Pelit, Soybalı ve Ak, 2017; Özkan, 2017; Tan, 2017; Oğan ve 
Akar Şahingöz, 2018). Elshaer ve Marzouk (2020: 160), hizmet sektöründe çalışan kişilerin sabra oldukça ihtiyaç duyduklarını ve müşterilerle başarılı bir iletişim kurmaları için gerekli bir beceri olduğunu belirtmektedirler. Ayrıca literatürde çalışanların sabırlı davranışlarının, müşteri şikayetleri ile memnuniyetsizliklerini çözmede etkili bir faktör olduğunu ve memnuniyet düzeyini arttırdığını savunan araştırmacılar vardır (Grandey, Fisk ve Mattila, 2005; Kuo, 2007). Yapılan bir araştırmada otel personelinin sabırlı davranışlarının müşteriler tarafından olumlu algılandığı ortaya çıkmıştır (Yilmaz, 2018: 20-21).

Literatürde kişilerin sabır tutumunu ölçen birçok araştırma mevcuttur (Schnitker, 2012; Doğan, 2014; Ro, 2014; Gençdoğan, Gülbahçe ve Gülbahçe, 2015; Habeeb, 2016; Karakaş, 2016; Oodariah ve Puspitasari, 2016; Doğan, 2017; Eliüşük Bülbül ve Izgar, 2017; Valikhani, Moustafa ve Karimi, 2017; Gül ve Çeliköz, 2018; Ibn Rasoul Sanaati, Hossein Sabet ve Motamedi, 2018; Karakaş, 2018; Kaytez ve Güngör Aytar, 2018; Özdemir, 2018; Akyol, 2019; Ateş ve Kayıklık, 2019; Eliöz, Çebi, İmamoğlu, İslamoğlu ve Yamak, 2019; Ermiş ve İmamoğlu, 2019; Kıral, 2019; Koç ve Arslan, 2019; Türkgeldi, 2019). Ancak turizm sektöründe çalışan bireylerin sabır tutumunu ölçen ampirik bir araştırmaya henüz rastlanmamıştır. Turizm çalışanlarında mutlaka bulunması gereken özelliklerden biri olan sabır özelliğinin çalışanlar üzerinde araştırılmamasının bir eksiklik olduğu düşünülmektedir. Hizmet sektörünün dinamiklerinden olan ve ülkelere önemli ekonomik katkılar sağlayan turizm sektöründe böyle bir araştırma yapılmamış olması araştırmacıları bu konuya yöneltmiştir. Bu çalışmanın temel amacı turizm sektöründe sabrın önemine dikkat çekmektir. Bu çerçevede çalışma ile konaklama işletmelerinde çalışan ön büro ve servis personelinin sabır düzeylerinin ampirik olarak analiz edilmesi amaçlanmıştır. Bu amaca bağlı olarak, ön büro ve servis personelinin sabır düzeyinin demografik ve mesleki değişkenlere göre farklılık gösterip göstermeyeceğinin belirlenmesi de hedeflenmiştir. Bu çalışmanın konaklama işletmelerinde örgütsel iletişime fayda sağlayacağı ve literatüre katkı sunacağı düşünülmektedir.

Yapılan bu araştırmada; Kahramanmaraş'ta faaliyet gösteren turizm belgeli konaklama işletmelerinde istihdam edilen ön büro ve servis personellerinin sabır düzeylerinin belirlenmesi ile sabır düzeylerinin demografik ve mesleki değişkenlere göre farklılık gösterip göstermediği ortaya konulmaya çalışılmıştır. Araştırma kapsamında giriş bölümünün ardından ikinci ana başlıkta sabır kavramının kavramsal çerçevesi yer almaktadır. Üçüncü ana başlıkta çalışmanın metodolojisi ortaya konulduktan sonra dördüncü ana başlıkta analiz sonuçlarından elde edilen bulgulara yer verilmiştir. Son olarak sonuç kısmında ise elde edilen bulgular tartışılmış ve elde edilen sonuçlar doğrultusunda birtakım öneriler sunulmuştur.

\section{KAVRAMSAL ÇERÇEVE}

\section{Sabır Kavramı ve Sabrın Önemi}

Sabır kavramının darlıkta kendini tutmak, engellemek, hapsetmek, Allah'tan başka kimseye sızlanmamak ve dili şikâyetten korumak, gerekli durumlarda nefsi hapsetme, kendini tutma, iradesine hâkim olma gibi birçok anlamı vardır (Yıldız, 2016: 129). TDK'nın tanımına göre ise; "Acl, yoksulluk, haksızlık vb. üzücü durumlar karşısında ses çıkarmadan onların geçmesini bekleme erdemi, dayanç", ikinci anlam olarak da; "Olacak veya gelecek bir şeyi telaş göstermeden bekleme" şeklinde tanımlanmıştır (http://sozluk.gov.tr/). Ahlâki manada ise, "üzüntü, başa gelen sıkıntı ve belalar karşısında direnç gösterme; olumsuzlukları olumlu kılmak için gösterilen metanet" olarak açıklanmaktadır (Ege, 2013: 71).

Sabır, diğer erdemlerin üzerinde geliştiği temel bir erdemdir. Bu yönüyle metanet, azim, sebat gibi erdemler bizzat sabır manasını içinde barındırırken, umut, hoşgörü, şükür, alçakgönüllülük gibi erdemler de sabırla güçlü bir ilişki içerisindedir. Öfke, şikâyet ve acelecilik kavramları ise 
sabırla uyuşmamaktadır (Doğan ve Gülmez, 2014: 265). Ayrıca sabır, birey ahlâkında toplum üyelerinden beklenilen iyi davranış kalıpları ve toplum içerisinde uyulması beklenilen kurallar içerisinde bulunmaktadır (Aktan, 2011: 68). Güzel ahlâkın unsurlarından biri olan sabır, teorisyenler tarafından psikolojik iyilik hali olarak kabul edilmektedir. Sabır, olgunlaşmış bireyin en temel özelliklerindendir (Doğan, 2014: 3).

Sabır, insanlara yaşadıkları üzücü veya zor durumlar karşısında dik durabilmeyi ve ümitsizlikten kurtulmasını sağlamaktadır. Ümitsizlik bireyi depresyona yöneltebilir. Depresyon ve karamsarlıktan kurtulmada sabır ve tevekkül önde gelmektedir. Kur'an' da bu iki kavram beraber zikredilmektedir. Sabır; acı ve üzüntüyü hafifleten, dünya hayatını daha anlamlı ve yaşanılır hale getiren bir olgudur (Ateş, 2019: 65). Bireyin sosyal hayatında karşılaştığı zorluk ve sıkıntılara gögüs germesinin adı sabırdır. Sabır, bireye ciddiyet ve saygınlık ile birlikte olgunluk da kazandırır. Sabırlı insanlarda daha az stres, düşük depresyon, daha az sağlık problemleri ve artan yaşam doyumu görülmektedir. Sabır, bireyleri olumsuz duygulardan kurtaran ve yaşam kalitesini artıran insani bir değerdir (Okçu ve Pilatin, 2018: 103). Sabır içsel tutarlılıktır. Duyguları yönetmeyi, zorluklara dayanmayı ve yapılan işlerde titiz olunmasını sağlar (Ibn Rasoul Sanaati, Hossein Sabet ve Motamedi, 2018: 211).

Sabrın bireysel açıdan çok önemli faydaları vardır. Sabırlı bir kişi ani kararlar değil rasyonel kararlar verme eğilimindedir. Ayrıca sabır gösterildiğinde olumsuz duygu ve depresyonu azalmaktadır. Fakat sabır gösterilmediğinde ise baş ağrısı ve akne gibi psikosomatik semptomlar görüldüğü belirtilmektedir. Sabrı düşük olan birey öfke ve çaresizlik içinde tükenmiş hissedebilir, ömrü kısaltan hastalıklara neden olabilecek toksik duygular ve kronik stres ile karşılaşabilir. Sabrın olumsuz psikosomatik rahatsızlıkları yönetmede etkili olduğu ifade edilmektedir. Bunların yanında sabır kişinin yaşam amacını, yaşam memnuniyetini ve başa çıkma düzeyini artırmaktadır. Sabırlı olmak kişinin yaşamsal, sosyolojik, psikolojik ve fizyolojik sağlık durumunu olumlu etkilemektedir. Sabrın örgütsel açıdan da birçok faydası bulunmaktadır. Bir personel çalıştığı işyerinin gelişimi ve büyümesi için karşılaştığı zorluklarla mücadele etmelidir. Bu mücadelede en önemli yardımcı unsur sabırdır. Sabır kişiler arasında iletişim ve etkileşimi artırdığından örgütsel performansı yükseltmektedir. Sabrın bir diğer örgütsel faydası ise etik davranış eğilimi geliştirmesidir. Baskı altında hızıı bir şekilde karar veren sabırsız kişiler etik dışı seçimler yapabilirler. Fakat sabırlı kişiler dürtüleri ile hareket etmeyip, örgüt için en doğru kararı verebilirler. Bununla birlikte çalışma ortamında birtakım olumsuz veya strese sebep olabilecek durumları yönetmek yine sabırla mümkün olabilir. Sabırlı davranışlar örgüt yaşamında uzun süreli refah sağlamaktadır (Kıral, 2019: 256-257).

\section{Konaklama İşletmeleri ve Sabır}

Dünya genelinde hızla gelişmekte olan turizm sektörü hem gelişmiş hem de gelişmekte olan ülkeler tarafından fazlasıyla ilgi görmektedir. Bunun temel sebeplerinden birisi turizmin ülke ekonomilerine katkı sağlamasıdır (Yıldız, 2011: 54). Ülkelerin gelişmişlik seviyelerine göre turizm sektörüne yönelik hedefleri değişiklik göstermektedir. Gelişmiş ülkeler turizm sektörünün gelir etkisinden yararlanırken, gelişmekte olan ülkeler ise istihdam gücünden yararlanmaktadır. Çünkü gelişmekte olan ülkelerin en önemli ekonomik sorunlarından biri işsizliktir. Turizm sektörü bu sorunun çözümünde etkin rol oynamaktadır. Otomasyon ve mekanizasyon imkânlarının sınırlı olduğu turizm sektöründe, diğer sektörlere oranla daha yüksek istihdam sağlanmaktadır (Şit, 2016: 102). Özellikle konaklama işletmeleri emek-yoğun bir özellik gösterir. Bu endüstride üretilen ve sunulan hizmetlerin büyük bir bölümü insan gücüne dayanmaktadır. Otomasyon sistemlerindeki gelişmelere rağmen konaklama işletmelerinde hala karşılama, yatak 
yapımı, telefonlara cevap verme, servis vb. hizmetler insanlar tarafından yapılmaya devam etmektedir (Ünüvar, 2009: 380).

Turizm işletmelerinde çalışan personel sayısı, benzer büyüklükteki bir endüstri işletmesine göre daha fazladır. Ayrıca bu sektörde çalışacak personel genelde hizmet sunduğu için bu personelde önemli bazı farklı özellikler aranmaktadır (Pelit ve Öztürk, 2011: 6-7). Otel işletmelerinde çalışan işgörenlerin sahip olduğu nitelik ve kişisel özellikleri işletme açısından başarı anahtarı olarak görülmektedir. Bu nedenle özellikle müşteri ile birebir iletişim halinde olan işgörenlerin sahip olması gereken birtakım niteliklerden söz edilebilir. Otel işletmelerinde çalışan personellerde mesleğini sevmek, iletişim becerisi, nazik, hoşgörülü, çabuk sinirlenmeyen, sakin, yardımsever, sabırll, misafirperver, dürüst, güvenilir, sorumluluk sahibi, saygıll, disiplinli, iyi bir dinleyici, enerjik, güler yüzlü, ekip çalışmasına yatkın, en az bir yabancı dil bilen, mesleki turizm eğitimi almak gibi özellikler bulunmalıdır (Tan, 2017: 4-5).

Küresel iş piyasasında kârlılık kaynaklarından biri de verimli personellerdir. Özellikle hizmet sektöründe kârlılığın büyük ölçüde personele bağlı olduğu belirtilmektedir. Örneğin hizmet sektörü içerisinde yer alan otel işletmeleri çalışanlarının örgütsel çıktılar üzerinde (rekabet stratejileri vb.) doğrudan etkileri vardır ve bu bakımdan çalışanlar, otel işletmelerinin bel kemiğini konumundadırlar. Emek yoğun olan bu işletmelerde hem sürdürülebilirlik hem de rekabet avantajı sağlanmasında yetkin personel çalıştırmanın önemli bir payı vardır. Doğru personelin seçilmesinin, müşteri ilişkilerinde başarıyı artıracağı belirtilmektedir. Otel işletmeleri farklı işletmeler ile karşılaştııldığında insan gücünün daha fazla olduğu işletmelerdir. Bu işletmelerde yapılan üretim yani hizmet en çok insana dayandığ i için otel personeli birer üretim faktörü olarak nitelendirilebilir. Bu sebeple bu üretim faktörünün, daha işin başındayken iyi seçilmesi gerekmektedir. Turizm sektöründe doğru personel seçimi ile verimlilik ve dolayısıyla kâr artışı sağlanabilir. Bu yüzden bu sektörde eleman alımlarında işletmenin kültürü, ne tip kişilerin işletmeye uygun olduğu, işin özelliklerine göre personel seçilmesi önerilmektedir. İşletmelerin başarısı doğru personelin istihdam edilmesine bağlıdır ve personel seçimi insan kaynakları departmanı için oldukça önemlidir. Konaklama işletmelerinde personel politikalarının amacı, iş gücünden en iyi şekilde faydalanmak, iş ilişkilerini işveren ve işgören açısından en iyi şekilde düzenleyebilmektir. Birtakım kişisel özelliklere ve niteliklere sahip kişilerin otel işletmelerinde daha başarılı olacağı öne sürülmektedir. Bu bağlamda ciddi, sorumluluk sahibi, öfkesini kontrol edebilen, enerjik, düzenli, titiz, kurallara uyan, sabırl, uyumlu, yardımsever ve dürüst kişilerin otel işletmelerinde başarılı olabileceği belirtilmektedir. $\mathrm{Bu}$ niteliklere sahip bireylerin otel işletmelerinde çalışması işletmenin yapısı açısından uygun olacağı vurgulanmaktadır (Özkan, 2017: 36-39).

Personele verilen görevin kişilik özelliği ile uyumlu olması çok önemlidir. Personel kendisine verilen görevden beklenen rolü oynamaktadır. Kişilik özellikleri ile rolün bağdaştırılması birey üzerinde olumlu etki yaparken, kişilik ile rol çatışması huzursuzluk, endişe ve bunun sonucunda istenmeyen davranışlara sebep olmaktadır. Kişilik özelliği yaptığı işe uygun olmayan bir bireyin kendi kişiliğine ve çevresine saygısı azalmaktadır. Bununla birlikte kendisini toplumdan soyutlanmıs, yalnız ve yabancı hissedebilir. Kaygı ve gerilim artarken davranış ve uyum bozuklukları da söz konusu olabilir. Bunun sonucunda ise iş yerinde çatışma ve huzursuzluklar ortaya çıkabilir. Kişisel verimlilik düştükçe, örgütsel verimlilikte de düşebilir. Bu bakımdan çalışanların kendi kişiliğine uygun mesleklerde çalışması hem örgüt iç huzuru hem de çalışan performansı açısından önemlidir. Birey, bulunduğu örgüt ile kişiliği arasında bağlantı kurabildiğinde çalışma arkadaşlarına uyum sağlayabilmektedir (Tatar, 2013: 36).

Konaklama işletmeleri, hizmet işletmeleri olduğundan çalışanlarının kişiliğinin müşteri memnuniyeti önemli olduğu belirtilmektedir. Bu yüzden hangi kişilik özelliklerinin işletme başarısı için fayda sağlayacağının bilinmesi gereklidir. Turizm sektöründe çalışan bireylerin 
sahip oldukları kişilik özellikleri, iş arkadaşları, amirleri ve müşterilerle olan iletişim ve ilişkilerinde etkili olabilmektedir. Bu nedenle iş başvurularında kişinin çalışacağı işletmeye uygunluğunun belirlenmesi önemlidir (Pelit, Türkmen ve Yarmac1, 2010: 9-15). Örneğin Pelit, Soybalı ve Ak (2017: 68)'a göre termal otel işletmelerinde çalışan personellerde sabırlı kişilik özelliği taşımalıdır. Söz konusu işletmelerin müşteri profili genellikle daha çok anlayış, hoşgörü, sabır ve ilgi isteyen yaşlılar ve hastalardan oluşmaktadır. Özsoy ve Tayfun (2020: 1104), otel işletmelerinde müşterilerle karşılıklı iletişim halinde olan personellerin yumuşak başlı kişilerden seçilmesini önermektedirler (Özsoy ve Tayfun, 2020: 1104).

Otel işletmelerinde çalışan personelin büyük bir kısmı, müşteriler ile sürekli doğrudan temas halindedir (Olcay, Giritlioğlu ve Çıkmaz, 2014: 388). Bunlardan birincisi ön büro personelidir. "Otel işletmelerinin beyni olarak tanımlanan ön büro, müşterinin karşılandı ̆̆g, ağırlandığı ve uğurlandığı yerdir" (Demirtaş, 2010a: 26). Ön büro, müş̧teri ile otel arasındaki bağdır. Müşteri ilk izlenimini ön bürodan alır ve bu izlenim son derece önemli olduğu için müşterinin genel yargısını oluşturmada etkilidir. Bu yüzden ön büronun sunduğu hizmetler oldukça önem taşımaktadır. Müşteri, ön büronun vereceği hizmetlerle bağlantılı olarak otel hakkında bilgi sahibi olur. Ön büro bölümü rezervasyon aşamasından başlayarak müşterilerle ilk temasın kurulduğu, girişte karşılandığı, kayıt işlemlerinin yapıldığı, ağırlandığı ve giderken de uğurlandığı bir bölümdür. Bu yüzden otel içerisinde insan ilişkilerinin en yoğun yaşandığı bölümdür (Demirtaş, 2010a: 2631). Konuklarla sürekli iletişim halinde olan ön büro personeli kişisel temizlik ve görünümüne çok dikkat etmelidir. Bununla birlikte ön büro elemanının yürümesi, oturması, ses tonu ve konuşması hususları da önem teşkil etmektedir. Ön büro personeli çok iyi hizmet anlayışıyla çalışmalı, konuklara ve iş arkadaşlarına daima kibar, ciddi ve güler yüzlü davranmalıdır. Soruları isteyerek sabırlı bir şekilde yanıtlamalıdır. Ön büro personelinin, konukların her türlü sorunlarını dinlemek ve çözüm bulmak için ikna gücü, iyi bir konuşma ve empati yeteneğine sahip olması gerekir. Karşısındaki bireyin psikolojik özelliklerini dikkate alarak, davranışlarını ona göre ayarlayabilmesi müşteri memnuniyeti oluşturulması açısından da çok önemlidir. Özetle ön büro personeli yerine göre hareket edebilmeli, zor durumlarda kendine hakim olabilmeli ve konuklarla özverili bir şekilde ilgilenebilmelidir (Öztürk ve Pekduyurucu, 2009: 36).

Ön büro personelinin, müşteriyle olan kişilerarası iletişim esnasında, ses tonunu iyi ayarlamalı, konuklara hitap ederken "siz, hanımefendi, beyefendi" gibi hitaplarında yanında gerektiği halde "lütfen, rica ederim, izin verir misiniz" gibi ifadeler kullanmalıdır. Kişilerarası iletişim esnasında müşterilerin yüzüne bakmalı, göz teması yapılmalı, konuğun sözü kesmemeli, konukla tartı̧̧mamalı, kelimeleri net bir şekilde telaffuz etmeli ve argo kelimeler kullanmamalıdır. Sözlü iletişim esnasında kısa cümleler kurmalı ve cümlenin sonu "efendim" ile bitirilmeli ancak konuşmaktan kaçar gibi bir izlenim verecek kadar kısa konuşmamalı, konuşma sırasında öfkeli davranmamalıdır (Ünüvar, 2009: 381). Bu tür davranışlarda sabırlı bir tutum çok etkilidir. Ön büro personelinin başlıca uğraşı "insan" olduğundan çok farklı tipte konuklara uyum sağlamak, onların istekleri doğrultusunda çözümler sunabilmek gerçekten çok fazla sabır ve tecrübe gerektirir (Demirtaş, 2010b: 8). Otel işletmelerini ziyaret eden birçok farklı konuk tipi bulunmaktadır. Bu konuk tiplerinden bazılarında sabırlı bir tutum çok önemlidir. İnatçı ve kendini beğenmiş konuklara hizmet sunmak, büyük bir özveri, sabır ve anlayış ister. Bu konuklarla ilişkiler personeli için zor durumlara sokabilir. Bu tip konuklara karşı oldukça sabırlı olunmalı, nezaket ve anlayış elden bırakılmamalıdır (Demirtaş, 2010a: 118). Ön büro personeli konuk şikayetlerinde konuğu çok iyi dinlemelidir. Bunun için konuğa yoğunlaşmak, göz temasına dikkat etmek, konuğun sözünü kesmemek, sabırlı, anlayışlı olmak gerekir (Demirtaş, 2010b: 216-217).

Otel işletmelerinde müşteri müşteriler ile sürekli doğrudan temas halinde olan ikinci personel yiyecek-içecek personelidir. Susmuş (2002: 6)'a göre yiyecek-içecek departmanı, “bir otelin 
yiyecek- içecek ve servis olanaklarını sağlayan üretim departmanıdır". Yiyecek-içecek departmanı, otelin çeşitli restoranlarında, banket salonlarında, barlarında vb. yerlerde müşterilere sunulan yiyecek-içecek maddelerinin tedarik edilmesini, korunmasını ve depolarda saklanmasını sağlar (Sökmen, 2005: 49). Otelin bu bölümünde verilen hizmet, konukların uyanması ile başlayıp tekrar uyumasına kadar devam eder. Otelde konaklayan müşteriler yiyecek-içecek bölümü personeli ile karşılaşıp ondan birtakım hizmetler alırlar. Yiyecek-içecek bölümünde de hizmet kalitesinin sağlanması, oluşturulan organizasyon yapısına, istihdam edilen personelin bilgi ve becerisi ile yönetim politikalarının etkin şekilde uygulanmasına bağlı olmaktadır (Selviden Albayrak, 2012: 14-16). Otelin bu bölümünde kurulan kişilerarası iletişim konuğun otel hakkında olumlu bir algıya sahip olmasını sağlayabilir (Ünüvar, 2009: 382).

Konaklama işletmelerinde çalışan kişilerin durum ve olaylara sabırla yaklaşması çok önemlidir. Özellikle konuklarla direkt iletişim halinde olan çalışanların, konuk istek ve şikâyetlerini dinleme ve ilgilenme ile hizmet ve yardım etmede sabırlı bir tutum sergilemesi müşterilerin temel ve psikolojik ihtiyaçlarının karşılanmasında çok etkilidir (Öztürk ve Seyhan, 2005: 123).

Elshaer ve Marzouk (2020: 160)'a göre sabır, hizmet sektöründe çalışan kişilerin oldukça ihtiyaç duyduğu ve müşterilerle başarılı bir temas kurmalarını sağlayan bir beceridir. Sabır, işyerinde başarının önemli bir unsurudur. Örgüt ortamındaki olumsuz durumlarla başa çıkmak için sabır gereklidir. Otelcilik ve ağırlama endüstrisi alanında, çalışanlar sabır gerektiren ağır çalışma koşullarıyla karşılaşabilirler. Mesai nedeniyle uzun saatler boyunca çalışmaktadırlar. Örneğin mesainin sonuna doğru görevlerini yaparken dürtüleri hızlı tepki vermesine neden olabilir. Bu gibi durumlarda ve özellikle müşterilerle temasa geçildiğinde, sabır çok değerlidir. Taraflar arasında sabır olmadığında, daha sonra pişman olunan şeyler söylenebilir ve sağlıklı iletişim yok olabilir. Bunun sonucunda da müşteri memnuniyetsizliği ve mutsuz çalışanlar ortaya çıkar. Örgütsel başarısızlık ve dolayısıyla mali kayıplar söz konusudur. Bu nedenle sabır, müşterilerle başarılı bir ilişki sürdürmede önemlidir. Hemen hemen her örgütte çalışma koşulları, iş arkadaşları, amirler veya müşterilerle ilgili birçok sorun ortaya çıkabilir. Çalışan kişi böyle bir duruma sabırla yaklaşırsa gerek müşterilerin gerekse amirlerin gözünde iyi bir imaj oluşturarak güven kazanır. Müşterilerin ve yöneticilerin güvenini kazanmak, örgütsel gelişim için çok olumludur (Elshaer ve Marzouk, 2020: 160-161).

\section{YÖNTEM}

\section{Araştırmanın Modeli}

Yapılan bu araştırma ilişkisel tarama modelinde tasarlanmıştır. "Kişilerin belirli bir konudaki tutum, inanç, görü̧s, davranış, beklenti ve özelliklerini anketler yardımıyla tespit etmeyi amaçlayan araştırmalara tarama araştırmaları" denir. İliş̧kisel tarama araştırmalarında genellikle iki veya daha fazla değişken arasındaki ilişkiler ortaya çıarılmaya çalışılır (Gürbüz ve Şahin, 2016: 107-109). Araştırma modeli Şekil 1'de sunulmaktadır. Modelde görüldügüü üzere ön büro ve servis elemanlarının sabır düzeyinin demografik ve mesleki özelliklerine göre farklılık gösterip göstermediği incelenmiştir.

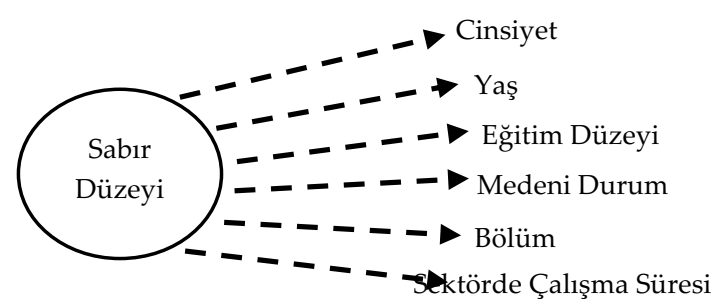

Şekil 1. Araştırmanın Modeli 


\section{Araştırmanın Problemi ve Hipotezleri}

Sabır, insanların karşılaştıkları kritik bir durumu soğukkanlı bir şekilde değerlendirerek sağlıklı bir karara varmasını ve problemlerle baş etmesini sağlamaktadır (Doğan, 2016: 3224). Hayatın her alanında sabır gösterilmesi gereken durumlar olabilir. Günlük hayatta zaman zaman evde, okulda, iş yerinde birtakım olumsuzluklar veya anlaşmazlıklar yaşanabilmektedir. Böyle durumlarda öfkelenmek yerine sabırla orta yolu bulabilmek kişilerarası iletişime katkı sağlar. Bu bağlamda sabır, sosyal hayatta ortaya çıkan problemlerinin çözülmesinde yardımcı olmaktadır (Doğan ve Gülmez, 2014: 269). Özellikle çalışma şartlarının ağır olduğu turizm sektöründe çalışanların sabırlı olmaları zorluklarla baş etmesine yardımcı olmaktadır. Turizmin hizmet sektörü olması yani insanın insana hizmet etmesi (Pelit vd., 2010: 9) sebebiyle çalışanlarda aranan temel bir özellik de sabırdır. Örneğin; odasını veya yemeğini beğenmeyen bir müşteriye sabırla yaklaşmak en doğru tutumdur.

Hizmet sektöründe faaliyet gösteren örgütlerde sabır gerektiren durumlar yaşanabilmektedir. Örneğin otelcilik ve ağırlama endüstrisinde çalışan kişiler, mesai yaparlar ve uzun saatler boyunca çalışırlar. Bu çalışma temposu fiziksel ve zihinsel yorgunluğu beraberinde getirirken sabrın zorlanmasına neden olabilir. Fakat turizm işletmelerinde sabır çok değerlidir. Çünkü sabrın olmadığı yerde sağlıklı iletişimden söz edilemez. Bu nedenle sabır, müşterilerle başarılı bir ilişki sürdürmede önemlidir (Elshaer ve Marzouk, 2020: 160). Öte yandan müşterilerin makul olmayan talepleri ve imkansız beklentileri, aşırı öfkeli ve sabırsız müşteriler otel personelini zor duruma sokabilir. Bu bağlamda otel çalışanlarının sabra ihtiyaç duymaları kaçınılmazdır.

Araştırmanın problemleri: "Kahramanmaraş ilinde faaliyet gösteren turizm belgeli otel işletmelerinde çalışan ön büro ve servis personelinin sabır düzeyleri yüksek midir?" ile “Kahramanmaraş ilinde faaliyet gösteren turizm belgeli otel işletmelerinde çalışan ön büro ve servis personelinin sabır düzeyleri ile demografik ve mesleki özellikleri arasında istatistiksel olarak anlamlı bir fark var mıdır?" olarak belirlenmiştir. Bu problemlerden hareketle araştırmanın hipotezleri şu şekilde belirlenmiştir:

H1: Ön büro/servis elemanlarının sabır düzeyleri yüksektir.

H2: Ön büro/servis elemanlarının sabır düzeyleri ile cinsiyetleri arasında istatistiksel olarak anlamlı bir farklılık vardır.

H3: Ön büro/servis elemanlarının sabır düzeyleri ile yaşları arasında istatistiksel olarak anlamlı bir farklılık vardır.

H4: Ön büro/servis elemanlarının sabır düzeyleri ile eğitim düzeyleri arasında istatistiksel olarak anlamlı bir farklılık vardır.

H5: Ön büro/servis elemanlarının sabır düzeyleri ile medeni durumları arasında istatistiksel olarak anlamlı bir farklılık vardır.

H6: Ön büro/servis elemanlarının sabır düzeyleri ile çalıştığı bölüm arasında istatistiksel olarak anlamlı bir farklılık vardır.

H7: Ön büro/servis elemanlarının sabır düzeyleri ile sektörde çalışma süreleri arasında istatistiksel olarak anlamlı bir farklılık vardır.

\section{Araştırmanın Amacı ve Önemi}

$\mathrm{Bu}$ araştırmanın temel amacı, Kahramanmaraş'ta faaliyet gösteren turizm belgeli konaklama işletmelerinde istihdam edilen ön büro ve servis personelinin sabır düzeyinin belirlenmesi ile 
demografik ve mesleki değişkenlere göre farklılaşıp farklılaşmadığını tespit etmektir. Ön büro ve servis personelleri üzerinde yapılan bu çalışma doğrultusunda otel işletmelerinde örgütsel iletişime fayda sağlanabilir. Bununla beraber alan yazında turizm personelinin sabır düzeyini inceleyen bir çalışma olmadığı için alan yazına katkı sunulabileceği düşünülmektedir.

\section{Veri Toplama Aracı ve Süreci}

Otel işletmelerinde istihdam edilen ön büro ve servis elemanlarının sabır düzeylerinin incelendiği bu araştırmada birincil veri toplama tekniklerinden olan anket tekniğinden yararlanılmıştır. Hazırlanan anket formu iki bölümden oluşmaktadır. Birinci bölümde katılımcların demografik ve mesleki özelliklerine ilişkin sorular yer almaktadır. İkinci bölümde ise katılımcıların sabır düzeylerini belirlemeye yönelik 40 soru yer almaktadır. Anket formunun bu bölümünde ise Schnitker (2012)'in Sabır Ölç̧eği ile Erken (2009)'in Sabırlı Davranış Ölçeği araştırma kapsamına uygun bir şekilde uyarlanarak kullanılmıştır. Araştırmada kullanılan ölçeğin kapsam geçerliliği bir uzman tarafından incelenmiş ve anketin ölçmek istenilen özelliği karşıladığ 1 tespit edilmiştir. Diğer yandan anketin görünüş geçerliliği bakımından sade ve anlaşılır olduğuna karar verilmiş ve ankete son şekli verilerek ölçek konaklama işletmelerine uyarlanmıştır. Bu bölümde yer alan ifadeler, 1=Kesinlikle Katılmıyorum, 2=Katılmıyorum, 3=Ne Katılıyorum Ne Katılmıyorum, 4=Katılıyorum, 5=Kesinlikle Katılıyorum şeklinde olmak üzere 5’li Likert tipi ölçekle derecelendirilmiştir. Anket formu, 2019 yılının Şubat-Mart aylarında Kahramanmaraş'ta faaliyet gösteren turizm belgeli otel işletmelerinin ön büro ve yiyecek-içecek departmanında çalışan işgörenler üzerinde bırak-topla yöntemi izlenerek uygulanmıştır.

\section{Uygulanan İstatistiksel Yöntemler}

Araştırma kapsamında toplanan veriler IBM SPSS 21.0 for Windows paket programı ile analiz edilmiştir Araştırmanın öncelikle güvenilirlik ölçümü yapılmış ve araştırmada kullanılan ölçeğin Cronbach's Alpha değerinin 0,937 olduğu tespit edilmiştir. Özdamar (1999: 522)'a göre 0,80'den yukarı Alpha değerine sahip olan ölçek değerleri "yüksek derecede" güvenilirdir. Katılımcıların demografik ve mesleki özelliklerinin analizinde frekans analizi ve yüzde dağılımı kullanılmıştır. Katılımcların sabır düzeylerinin tespitinde ise aritmetik ortalama ve standart sapma değerleri yorumlanmıştır. Anket sorularının daha iyi yorumlanabilmesi için Tablo 1'de ifadeler; "Kesinlikle Katıliyorum" seçeneğinden başlamak üzere 5'den 1'e doğru puanlanma yoluna gidilmiş ve "Kesinlikle Katılıyorum" seçeneği ise çok yüksek, "Katıllyorum" seçeneği yüksek, "Ne Katılıyorum Ne Katılmıyorum" seçeneği orta, "Katılmıyorum" seçeneği düşük, "Kesinlikle Katılmıyorum" seçeneği çok düşük olarak değerlendirilmiştir. Aritmetik ortalamaların eşik değerleri ise şu şekilde hesaplanmıştır (Olcay ve Sürme, 2014: 842):

$$
\begin{aligned}
& \text { Değişim Aralığ } 1 \text { (Range) }=5-1=4 \\
& \text { Değişim Aralığ } 1 \text { (Range) }=4 / 5=0,80
\end{aligned}
$$

Tablo 1. Aritmetik Ortalamaların İsabet Ettiği Seçeneklerin Aralık Değerlerine Göre Dağılımı

\begin{tabular}{|c|c|c|c|}
\hline Ağırlık & Seçenekler & $\begin{array}{c}\text { Aritmetik Ortalamaların Ağırlık } \\
\text { Değerleri }\end{array}$ & Sonuç \\
\hline $\mathbf{5}$ & Kesinlikle Katılıyorum & $4.20-5.00$ & Çok Yüksek Düzey \\
\hline $\mathbf{4}$ & Katılıyorum & $3.40-4.19$ & Yüksek Düzey \\
\hline $\mathbf{3}$ & $\begin{array}{c}\text { Ne Katılıyorum Ne } \\
\text { Katılmiyorum }\end{array}$ & $2.60-3.39$ & Orta Düzey \\
\hline $\mathbf{2}$ & Katılmiyorum & $1.80-2.59$ & Düşük Düzey \\
\hline $\mathbf{1}$ & Kesinlikle Katılmiyorum & $1.00-1.79$ & Çok Düşük Düzey \\
\hline
\end{tabular}


Verilerin normal bir dağılım gösterip göstermediğini tespit edebilmek için ilk olarak Kolmogorov-Smirnov Testi $(\mathrm{n}>50)$ yapılmıştır. Bu test sonucunda Kolmogorov-Smirnov değerinin $p=0,000$ olduğu ve verilerin normal dağılmadığ $(p \leq 0,05)$ görülmüştür. Daha sonra veri setinin çarpıklık (skewness) ve basıklık (kurtosis) değerleri incelenmiştir. Şencan (2005: 200-201), normal bir dağılım için çarpıklık ve basıklık değerlerinin \pm 1 sınırları içinde; $\mathrm{z}$ istatistiğinin ise \pm 2 sınırları içinde olması gerektiğini belirtmiştir. Bu testin sonucunda ise çarpıklık değerinin -1,273 ve basıklık değerinin 1,094 olduğu görülmüştür. Öte yandan hesaplanan z-istatistiği çarpıklık için $-1,273 / 0,180=-7,07$; basıklık için 1,094/0,358=3,05 olarak bulunmuştur. Normallik testlerine ilişkin sonuçlar Tablo 2' de gösterilmiştir.

Tablo 2. Araştırma Verilerine İlişkin Normallik Testleri

\begin{tabular}{|c|c|c|c|c|c|c|c|c|}
\hline & \multicolumn{3}{|c|}{ Kolmogorov-Smirnov Testi } & \multicolumn{3}{|c|}{ Skewness (Çarpıklık) } & \multicolumn{3}{c|}{ Kurtosis (Basıklık) } \\
\cline { 2 - 9 } Sabır & İstatistik & $\mathrm{P}$ & İstatistik & Standart Hata & $\mathrm{z}$ & İstatistik & Standart Hata & $\mathrm{z}$ \\
Ölçeği & 0,146 & 0,000 & $-1,273$ & 0,180 & $-7,07$ & 1,094 & 0,358 & 3,05 \\
\hline
\end{tabular}

Son olarak histogram, Q-Q Plots ve box-plot grafikleri de incelenerek verilerin normal dağılıma sahip olmadığı sonucuna varılmıştır. Bu sonuçlar doğrultusunda analizlerde parametrik olmayan testler kullanılmıştır. Bu kapsamda katılımcıların sabır düzeylerinin demografik ve mesleki özelliklerine göre farklılık gösterip göstermediğini tespit edebilmek amacıyla da Mann Whitney U Testi ve Kruskal Wallis Testi analizleri uygulanmıştır.

\section{Araştırmanın Evreni ve Örneklemi}

Araştırmanın evrenini, Kahramanmaraş ili sınırları içerisinde faaliyet gösteren otel işletmelerinde çalışmakta olan ön büro ve servis personelleri oluşturmaktadır. Çalışmanın evrenin belirlenmesi için Kahramanmaraş İl Kültür ve Turizm Müdürlügü'nden bilgi alınmıştır. $\mathrm{Bu}$ kapsamda araştırma evrenini oluşturan tesis sayısının 24 olduğu bilgisine ulaşılmıştır. Bu tesisler araştırmacı tarafından tek tek ziyaret edilerek istihdam edilen ön büro ve servis personel sayısı öğrenilmiş ve araştırma evreninin 233 kişi olduğu sonucuna ulaşılmıştır. Ural ve Kılıç (2013: 43)'a göre 230-240 arası bir evrende \%95 güven aralığında 0,05 hata payı ile örneklem büyüklüğünün 148 olması gerekmektedir. Bu çalışmanın örneklemini Kahramanmaraş ilinde faaliyet gösteren turizm belgeli 24 otelin 182 ön büro ve yiyecek-içecek departmanı çalışanı oluşturmaktadır. Evreni oluşturan otel işletmelerinin tümü personel sayı bilgisini vermiş ancak bu otellerin hepsi anket kabul etmemiştir. Anket uygulamasını kabul eden otellere anketler bırakılmış ve daha sonra toplanmıştır. Toplamda 194 kişiye anket uygulanmış ancak 12 anket kontrol sorusunun işaretlenmesi sebebiyle değerlendirme dişı bırakılmıştır. Bunun sonucunda 182 anket analize tabi tutulmuştur. Dolayısıyla bu araştırmanın örneklem büyüklügünün araştırma evrenini temsil etme kapasitesine sahip olduğu düşünülmektedir.

\section{BULGULAR}

\section{Katılımcıların Demografik ve Mesleki Özellikleri}

Katılımcıların demografik ve mesleki özellikleri Tablo 3'de gösterilmiştir. Tablo 3 incelendiğinde erkek çalışan oranının $(\% 73,1)$, kadın çalışanlardan $(\% 26,9)$ daha fazla olduğu belirlenmiştir. En yüksek orana sahip yaş grubu 24-31 yaş (\%50) olup, evli çalışan oranı $(\% 56,6)$ bekâr çalışan oranından $(\% 43,4)$ yüksektir. Eğitim durumu verilerine bakıldığında en büyük grubun lise 
mezunu çalışanlar olduğu $(\% 51,1)$ olduğu görülmüştür. Katılımcların mesleki özelliklerine bakıldığında en çok ön büro departmanı çalışanlarından $(\% 53,8)$ oluştuğu görülmektedir. Araştırmaya katılanların \%44,5'inin turizm sektöründe 1-5 yıl arası çalıştığı belirlenmiştir.

Tablo 3. Katılımcların Demografik ve Mesleki Özellikleri

\begin{tabular}{|c|c|c|c|}
\hline & Katılımcıya İlişkin Özellikler & $(\mathrm{N})$ & $(\%)$ \\
\hline \multirow{3}{*}{ Cinsiyet } & Erkek & 133 & 73,1 \\
\hline & Kadın & 49 & 26,9 \\
\hline & Toplam & 182 & 100,0 \\
\hline \multirow{6}{*}{ Yaş } & $16-23$ & 34 & 18,7 \\
\hline & $24-31$ & 91 & 50,0 \\
\hline & $32-39$ & 33 & 18,1 \\
\hline & $40-47$ & 18 & 9,9 \\
\hline & 48 ve üzeri & 6 & 3.3 \\
\hline & Toplam & 182 & 100,0 \\
\hline \multirow{6}{*}{ Eğitim Dïzeyi } & İlkokul & 4 & 2,2 \\
\hline & Ortaokul & 16 & 8,8 \\
\hline & Lise & 93 & 51,1 \\
\hline & Önlisans & 41 & 22,5 \\
\hline & Lisans ve Üstü & 28 & 15,4 \\
\hline & Toplam & 182 & 100,0 \\
\hline \multirow{3}{*}{ Medeni Durum } & Evli & 103 & 56,6 \\
\hline & Bekâr & 79 & 43,4 \\
\hline & Toplam & 182 & 100,0 \\
\hline \multirow{3}{*}{ Bölüm } & Ön büro & 98 & 53,8 \\
\hline & Yiyecek-İçecek & 84 & 46,2 \\
\hline & Toplam & 182 & 100,0 \\
\hline \multirow{5}{*}{$\begin{array}{c}\text { Sektörde Çalışma } \\
\text { Süresi }\end{array}$} & 1 yıldan az & 26 & 14,3 \\
\hline & $1-5$ y1l & 81 & 44,5 \\
\hline & 6-10 y1l & 52 & 28,6 \\
\hline & 11 yıl ve üzeri & 23 & 12,6 \\
\hline & Toplam & 182 & 100,0 \\
\hline
\end{tabular}

\section{Katılımcıların Sabır Düzeylerine İlişkin Bulgular}

Bu bölümde katılımcıların sabır düzeylerini belirlemeye yönelik elde edilen aritmetik ortalama, standart sapma değerleri ile bu değerlerin ifade ettiği sonuçlar yer almaktadır. Buna göre elde edilen bulgular Tablo 4'te gösterilmiştir.

Tablo 4'te yer alan ifadelerin aritmetik ortalamaları ve standart sapmaları incelendiğinde, araştırma kapsamında sorulan 40 adet sorunun genel ortalamasının yüksek olduğu görülmektedir. Buna göre, "Ön büro/servis elemanlarının sabır düzeyleri yüksektir" (H1) hipotezi kabul edilmiştir.

Tablo 4'e göre katılımcıların sabır düzeylerine ilişkin en yüksek katılımın gerçekleştiği ifade "Misafirler herhangi bir konuda şikâyetlerini dile getirirken, onları sonuna kadar dinlerim $(4,75 \pm 0,52)$ " olduğu görülmüştür. Çok yüksek düzeyde katılım gösteren ifadeler ise sirasiyla "Otel kurallarına uymayan konuklara uymaları gereken kuralları nezaketle söylerim $(4,63 \pm 0,72)$ ", "Çalıştığım bölümde her zaman düşünerek hareket ederim $(4,62 \pm 0,56)$ ", " "Çalışma esnasında karşılaştı̆̆ım zor durumlarla mücadele ederim $(4,58 \pm 0,69)$ ”, " Müssterinin herhangi bir konuda problemi olduğunda telaşlanmadan sorunu çözmeye çalışırım $(4,54 \pm 0,75)$ ", "Görev aldığım birimde yaşadığım sıkıntılara katlanırım $(4,53 \pm 0,76)^{\prime \prime}$, "Çok yoğun olsam bile müşterinin istek ve ihtiyaçlarını karşılamaya çaba sarf ederim $(4,49 \pm 0,71)$ ", "Hasta veya uykusuz olduğum zamanlarda bile işime gereken önemi vermeye çalışırım $(4,47 \pm 0,66)$ ", "Çok yorgun olsam bile 
güler yüz ile sorunları çözmeye çalışırım $(4,44 \pm 0,79)$ ", "Çalışma hayatımda problemlerle karşılaştı̆̆ımda genellikle soğukkanlılığımı koruyabilirim $(4,29 \pm 0,87)$ ", "Kibarca uyarmama rağmen gürültü ve tatsızlık çıkaran konuğa sakince yaklaşırım $(4,22 \pm 1,08)^{\prime \prime}$ ifadeleridir.

Tablo 4. Katılımcıların Sabır Düzeylerine İlişkin Aritmetik Ortalama, Standart Sapma ve Sonuç Bulguları

\begin{tabular}{|c|c|c|c|c|}
\hline No & İFADELER & $\overline{\mathbf{x}}$ & S.S & Sonuç \\
\hline 1. & Konuk şikâyetleriyle baş etmede zorluk yaşamam & 4,18 & 1,16 & Yüksek \\
\hline 2. & Görev aldığım birimde yaşadığım sıkıntılara katlanırım & 4,53 & 0,76 & Çok Yüksek \\
\hline 3. & Çalışma esnasında karşılaştığım zor durumlarla mücadele ederim & 4,58 & 0,69 & Çok Yüksek \\
\hline 4. & $\begin{array}{l}\text { Misafirler herhangi bir konuda şikâyetlerini dile getirirken, onları sonuna kadar } \\
\text { dinlerim }\end{array}$ & 4,75 & 0,52 & Çok Yüksek \\
\hline 5. & Çalışma hayatımda öfkemi kontrol edebilirim & 4,18 & 0,96 & Yüksek \\
\hline 6. & Kibarca uyarmama rağmen gürültü ve tatsızlık çıkaran konuğa sakince yaklaşırım & 4,22 & 1,08 & Çok Yüksek \\
\hline 7. & Otel kurallarına uymayan konuklara uymaları gereken kuralları nezaketle söylerim & 4,63 & 0,72 & Çok Yüksek \\
\hline 8. & Terfi edilmeyeceğimi bilsem bile uzun yıllar aynı birimde/görevde çalışabilirim & 2,96 & 1,45 & Orta \\
\hline 9. & Çalışma arkadaşımın işimle ilgili beni uyarmasına öfkelenmem & 4,04 & 0,90 & Yüksek \\
\hline 10. & Çok yoğun olsam bile müşterinin istek ve ihtiyaçlarını karşılamaya çaba sarf ederim & 4,49 & 0,71 & Çok Yüksek \\
\hline 11. & $\begin{array}{l}\text { Çalışma hayatımda problemlerle karşılaştığımda genellikle soğukkanlılı̆̆ımı } \\
\text { koruyabilirim }\end{array}$ & 4,29 & 0,87 & Çok Yüksek \\
\hline 12. & Çalıştığım bölümde her zaman düşünerek hareket ederim & 4,62 & 0,56 & Çok Yüksek \\
\hline 13. & Çalışma hayatımda problemleri çözerken genellikle zorlanmam & 3,92 & 0,93 & Yüksek \\
\hline 14. & S1k sık birim/görev değişikliği beni sinirlendirmez & 2,86 & 1,36 & Orta \\
\hline 15. & Çalışma arkadaşlarıma işleri öğretirken tekrar tekrar anlatmak beni sıkmaz & 4,11 & 1,00 & Yüksek \\
\hline 16. & $\begin{array}{l}\text { Yapacak işim çok fakat zamanımın az olduğu durumlarda bile sakince } \\
\text { davranabilirim }\end{array}$ & 4,09 & 1,06 & Yüksek \\
\hline 17. & Çalıştığım alandaki mekanik veya elektronik cihazların bozulması beni kızdırmaz & 2,71 & 1,33 & Orta \\
\hline 18. & $\begin{array}{l}\text { Hasta veya uykusuz olduğum zamanlarda bile işime gereken önemi vermeye } \\
\text { çalışırım }\end{array}$ & 4,47 & 0,66 & Çok Yüksek \\
\hline 19. & Çok yorgun olsam bile güler yüz ile sorunları çözmeye çalışırım & 4,44 & 0,79 & Çok Yüksek \\
\hline 20. & Mesaimin bitişinde fazla mesai yapmam istenmesi beni sinirlendirmez & 3,93 & 1,25 & Yüksek \\
\hline 21. & İş yerinde yaşadığım sıkıntılardan genellikle yakınmam & 3,90 & 1,23 & Yüksek \\
\hline 22. & $\begin{array}{l}\text { Haksız yere azarlandığımı düşündüğümde bile sakince bu durumun geçmesini } \\
\text { beklerim }\end{array}$ & 3,36 & 1,37 & Orta \\
\hline 23. & Sinirli bir müşteriyle karşılaştığımda çoğunlukla müşteriyi sakinleştirebilirim & 4,15 & 1,08 & Yüksek \\
\hline 24. & Çalışırken "işler yeter ki bitsin de nasıl biterse bitsin" diye düşünmem & 3,81 & 1,38 & Yüksek \\
\hline 25. & Çalışırken gün içinde çok sık sinirlenmem & 3,85 & 0,95 & Yüksek \\
\hline 26. & Birçok işi aynı anda yapıp işleri hemen bitirmeye çalışmam & 3,88 & 1,24 & Yüksek \\
\hline 27. & Yöneticilerimin bana olan sert tavrına karşlık vermem & 3,69 & 1,35 & Yüksek \\
\hline 28. & Sorumluluklarını yerine getirmeyen çalışma arkadaşlarımı sürekli uyarııım & 4,03 & 0,89 & Yüksek \\
\hline 29. & Çoğu zaman işyerinde yaşadığım sıkıntılardan şikâyet etmem & 3,84 & 1,16 & Yüksek \\
\hline 30. & Genelde sakin bir insanımdır & 3,80 & 1,04 & Yüksek \\
\hline 31. & Uzun bir yazıyı baştan sona sabırla okuyabilirim & 3,75 & 1,10 & Yüksek \\
\hline 32. & Problem çıkaran müşterilere tahammül edebilirim & 4,04 & 1,12 & Yüksek \\
\hline 33. & Görevim haricinde bir iş yapmam gerektiğinde sinirlenmem & 3,52 & 1,36 & Yüksek \\
\hline 34. & Yapılması mümkün olmayan müşteri talepleri beni sinirlendirmez & 2,69 & 1,37 & Orta \\
\hline 35. & Problem yaşadığım iş arkadaşlarıma tahammül edebilirim & 3,93 & 0,99 & Yüksek \\
\hline 36. & Otelin yoğun olduğu zamanlarda telaşlanmam & 4,15 & 1,18 & Yüksek \\
\hline 37. & $\begin{array}{l}\text { Müşterinin herhangi bir konuda problemi olduğunda telaşlanmadan sorunu } \\
\text { çözmeye çalışırım }\end{array}$ & 4,54 & 0,75 & Yüksek \\
\hline 38. & $\begin{array}{l}\text { Müdürüm/şefim konuşurken, konuşmasını bitirmeden araya girer söylemek } \\
\text { istediğimi söylerim* }\end{array}$ & 3,82 & 1,38 & Yüksek \\
\hline 39. & Çalışırken sürekli saatime bakarım* & 3,47 & 1,40 & Yüksek \\
\hline 40. & Çalışma hayatımda genellikle çok konuşmayı severim* & 2,66 & 1,30 & Orta \\
\hline \multicolumn{2}{|r|}{ GENEL ORTALAMA } & 3,92 & 0,58 & Yüksek \\
\hline
\end{tabular}

Not=1,00-1,79: Çok Düşük Düzey; 1,80-2,59: Düşük Düzey; 2,60-3,39: Orta Düzey; 3,40-4,19: Yüksek Düzey; 4,20-5,00: Çok

Yüksek Düzey, N=182, $\left(^{*}\right)=$ Önermeler ters kodlanmıştır 
Yüksek düzeyde katılım sağlanan ifadeler ise sırasıyla "Konuk şikâyetleriyle baş etmede zorluk yaşamam $(4,18 \pm 1,16)$ ", "Çalışma hayatımda öfkemi kontrol edebilirim $(4,18 \pm 0,96)$ ", " Sinirli bir müşteriyle karşılaştığımda çoğunlukla müşteriyi sakinleştirebilirim $(4,15 \pm 1,08)$ ”, " Otelin yoğun olduğu zamanlarda telaşlanmam $(4,15 \pm 0,75)$ ", "Çalışma arkadaşlarıma işleri öğretirken tekrar tekrar anlatmak beni sıkmaz $(4,11 \pm 1,00)$ ", "Yapacak işim çok fakat zamanımın az olduğu durumlarda bile sakince davranabilirim $(4,09 \pm 1,06)$ ", "Çalışma arkadaşımın işimle ilgili beni uyarmasına öfkelenmem $(4,04 \pm 0,90)$ ", "Problem çıaran müşterilere tahammül edebilirim $(4,04 \pm 1.12)$ ", "Sorumluluklarını yerine getirmeyen çalışma arkadaşlarımı sürekli uyarıım $(4,03 \pm 0,89)$ ", "Mesaimin bitişinde fazla mesai yapmam istenmesi beni sinirlendirmez $(3,93 \pm 1,25)$ ", "Problem yaşadığım iş arkadaşlarıma tahammül edebilirim $(3,93 \pm 0,99)$ ", " Ç̧alışma hayatımda problemleri çözerken genellikle zorlanmam $(3,92 \pm 0,93)$ ", "İş yerinde yaşadığım sıkıntılardan genellikle yakınmam $(3,90 \pm 1,23)$ ", "Birçok işi aynı anda yapıp işleri hemen bitirmeye çalışmam $(3,88 \pm 1,24)$ ", "Çalışırken gün içinde çok sık sinirlenmem $(3,85 \pm 0,95)$ ", "Çoğu zaman işyerinde yaşadığım sıkıntılardan şikâyet etmem $(3,84 \pm 1,16)$ ", "Müdürüm/şefim konuşurken, konuşmasını bitirmeden araya girer söylemek istediğimi söylerim $(3,82 \pm 1,38)$ ", "Çalışırken "işler yeter ki bitsin de nasıl biterse bitsin" diye düşünmem $(3,81 \pm 1,38)$ ", "Genelde sakin bir insanımdır $(3,80 \pm 1,04)$ ", "Uzun bir yazıyı baştan sona sabırla okuyabilirim $(3,75 \pm 1,10)$ ", "Yöneticilerimin bana olan sert tavrına karşılık vermem $(3,69 \pm 1,35)$ ", "Görevim haricinde bir iş yapmam gerektiğinde sinirlenmem $(3,52 \pm 1,36)$ ", "Çalışırken sürekli saatime bakarım $(3,47 \pm 1,40)^{\prime \prime}$ ifadeleridir.

Orta düzeyde katılım gösterilen ifadeler ise sırasıyla "Haksız yere azarlandığımı düşündüğümde bile sakince bu durumun geçmesini beklerim $(3,36 \pm 1,37)$ ", "Terfi edilmeyeceğimi bilsem bile uzun yıllar ayn birimde/görevde çalışabilirim $(2,96 \pm 1,45)$ ", "Sık sık birim/görev değişikliği beni sinirlendirmez $(2,86 \pm 1,36)$ ", "Çalıştığım alandaki mekanik veya elektronik cihazların bozulması beni kızdırmaz $(2,71 \pm 1,33)^{\prime}$, " "Yapılması mümkün olmayan müşteri talepleri beni sinirlendirmez $(2,69 \pm 1,37)$ ", "Çalışma hayatımda genellikle çok konuşmayı severim $(2,66 \pm 1,30)$ " ifadeleridir. Düşük düzeyde katılım ve çok düşük düzeyde katılım sağlanan ifade bulunmamaktadır.

\section{Katılımcıların Demografik Özellikleri ile Sabır Düzeyleri Arasındaki Farklılık Analizleri}

Bu bölümde katılımcıların sabır düzeylerinin demografik ve mesleki değişkenlere göre farklılık gösterip göstermediği bulgulanmaya çalışılmıştır. Verilerin normal dağılım göstermemesi sebebiyle analizlerde Mann Whitney U Testi ile Kruskal Wallis Testi uygulanmıştır.

\section{Cinsiyet Değişkenine İlişkin Bulgular}

Katılımcıların cinsiyetleri ile sabır düzeyleri arasında istatiksel olarak anlamlı bir farklılığın olup olmadığını aramak amacıyla uygulanan Mann- Whitney U Testi'nden elde edilen bulgular Tablo 5'de gösterilmiştir.

Buna göre katılımcıların cinsiyetleri ile sabır düzeyleri arasında istatiksel olarak anlamlı bir farklılığın olmadığı tespit edilmiştir ( $p>0,05)$. Sonuç olarak "Ön büro/servis elemanlarının sabır düzeyleri ile cinsiyetleri arasında bir farklılık vardır" (H2) hipotezi reddedilmiştir. 
Tablo 5. Katılımcıların Sabır Düzeylerinin Cinsiyet Değişkenine Göre Farklılık Gösterip Göstermediğine İlişkin Mann Whitney U Testi Bulguları

\begin{tabular}{|c|c|c|c|c|c|}
\hline \multirow{2}{*}{ İfadeler } & \multicolumn{2}{|c|}{ Grup sıra ortalaması } & \multirow{2}{*}{ Mann-Whitney U Testi } & Z & P \\
\cline { 2 - 3 } \cline { 5 - 6 } & Kadın & Erkek & & -235 & 0,814 \\
\cline { 2 - 3 } & 89,99 & 92,06 & 3184,500 & & \\
\hline
\end{tabular}

\section{Yaş Değişkenine İlişkin Bulgular}

Katılımcların yaşları ile sabır düzeyleri arasında istatiksel olarak anlamlı bir farklılığın olup olmadığını aramak amacıyla uygulanan Kruskal Wallis Testi'nden elde edilen bulgular Tablo 6'da gösterilmiştir.

Tablo 6. Katılımcıların Sabır Düzeylerinin Yaş Değişkenine Göre Farklılık Gösterip Göstermediğine İlişkin Kruskal Wallis Testi Bulguları

\begin{tabular}{|c|c|c|c|c|c|c|c|}
\hline \multirow{3}{*}{ Iffadeler } & \multicolumn{5}{|c|}{ Grup sira ortalamas1 } & Ki-kare & P \\
\cline { 2 - 8 } & $16-23$ & $24-31$ & $32-39$ & $40-47$ & 48 ve üzeri & \multirow{2}{*}{6,670} & 0,154 \\
\cline { 2 - 6 } & 73,53 & 95,37 & 89,20 & 101,19 & 118,25 & & \\
\hline
\end{tabular}

Buna göre katılımcıların yaşları ile sabır düzeyleri arasında istatiksel olarak anlamlı bir farklılığın olmadığı tespit edilmiştir ( $p>0,05)$. Sonuç olarak "Ön büro/servis elemanlarının sabır düzeyleri ile yaşları arasında bir farklılık vardır" (H3) hipotezi reddedilmiştir.

\section{Eğitim Değişkenine İlişkin Bulgular}

Katılımcıların eğitim düzeyleri ile sabır düzeyleri arasında istatiksel olarak anlamlı bir farklılığın olup olmadığını aramak amacıyla uygulanan Kruskal Wallis Testi'nden elde edilen bulgular Tablo 7'de gösterilmiştir.

Tablo 7. Katılımcıların Sabır Düzeylerinin Eğitim Değişkenine Göre Farklılık Gösterip Göstermediğine İlişkin Kruskal Wallis Testi Bulguları

\begin{tabular}{|c|c|c|c|c|c|c|c|}
\hline \multirow{3}{*}{ İfadeler } & \multicolumn{5}{|c|}{ Grup sira ortalaması } & Ki-kare & P \\
\cline { 2 - 8 } & İlkokul & Ortaokul & Lise & Ön lisans & Lisans ve üstü & \multirow{2}{*}{5,991} & 0,200 \\
\cline { 2 - 6 } & 81,25 & 93,78 & 84,02 & 95,32 & 110,63 & & \\
\hline
\end{tabular}

Buna göre katılımcıların eğitim düzeyi ile sabır düzeyleri arasında istatiksel olarak anlamlı bir farklılığın olmadığı tespit edilmiştir ( $>>0,05)$. Sonuç olarak "Ön büro/servis elemanlarının sabır düzeyleri ile eğitim düzeyi arasında bir farklılık vardır" (H4) hipotezi reddedilmiştir.

\section{Medeni Durum Değişkenine İlişkin Bulgular}

Katılımcıların medeni durumları ile sabır düzeyleri arasında istatiksel olarak anlamlı bir farklılığın olup olmadığını aramak amacıyla uygulanan Mann- Whitney U Testi'nden elde edilen bulgular Tablo 8'de gösterilmiştir.

Buna göre katılımcıların medeni durumları ile sabır düzeyleri arasında istatiksel olarak anlamlı bir farklılığın olduğu tespit edilmiştir $(\mathrm{p}<0,05)$. Sonuç olarak "Ön büro/servis elemanlarının sabır düzeyleri ile medeni durumları arasında bir farklılık vardır" (H5) hipotezi kabul edilmiş olup farklılıkların hangi ifadelerde gerçekleştiğini görmek için Mann-Whitney U Testi uygulanmış ve elde edilen bulgular Tablo 9'da gösterilmiştir. 
Tablo 8 Katılımcıların Sabır Düzeylerinin Medeni Durum Değişkenine Göre Farklılık Gösterip Göstermediğine İlişkin Mann Whitney U Testi Bulguları

\begin{tabular}{|l|c|c|c|c|c|}
\hline \multirow{2}{*}{ İfadeler } & \multicolumn{2}{|c|}{ Grup sira ortalamas1 } & \multirow{2}{*}{ Mann-Whitney U Testi } & Z & P \\
\cline { 2 - 3 } \cline { 5 - 6 } & Evli & Bekâr & & $-3,338$ & $\mathbf{0 , 0 0 1}$ \\
\cline { 2 - 3 } & 102,91 & 76,62 & 2893,000 & & \\
\hline
\end{tabular}

Tablo 9. Katılımcıların Medeni Durumları ile Sabır Düzeylerinin İfadelere Göre Karşılaştırılmasına İlişkin Mann Whitney U Testi Sonuçları

\begin{tabular}{|c|c|c|c|c|}
\hline \multirow[t]{2}{*}{ İfadeler } & \multicolumn{2}{|c|}{ Medeni Durum } & \multirow[t]{2}{*}{$\mathbf{Z}$} & \multirow[t]{2}{*}{$\mathbf{P}$} \\
\hline & Evli & Bekâr & & \\
\hline Konuk şikâyetleriyle baş etmede zorluk yaşamam & 98,63 & 82,20 & $-2,314$ & 0,02 \\
\hline Görev aldığım birimde yaşadığım sıkıntılara katlanırım & 100,36 & 79,95 & $-3,094$ & 0,00 \\
\hline Çalışma esnasında karşılaştığım zor durumlarla mücadele ederim & 95,15 & 86,74 & $-1,293$ & 0,19 \\
\hline $\begin{array}{l}\text { Misafirler herhangi bir konuda şikâyetlerini dile getirirken, onları sonuna kadar } \\
\text { dinlerim }\end{array}$ & 92,67 & 89,97 &,- 476 & 0,63 \\
\hline Çalışma hayatımda öfkemi kontrol edebilirim & 94,16 & 88,03 &,- 843 & 0,39 \\
\hline Çalışma hayatımda genellikle çok konuşmayı severim* & 83,94 & 101,35 & $-2,266$ & 0,02 \\
\hline Kibarca uyarmama rağmen gürültü ve tatsızlık çıaran konuğa sakince yaklaşırım & 97,99 & 83,04 & $-2,098$ & 0,03 \\
\hline Otel kurallarına uymayan konuklara uymaları gereken kuralları nezaketle söylerim & 94,93 & 87,03 & $-1,285$ & 0,19 \\
\hline Terfi edilmeyeceğimi bilsem bile uzun yıllar aynı birimde/görevde çalışabilirim & 94,95 & 87,01 & $-1,037$ & 0,30 \\
\hline Çalışma arkadaşımın işimle ilgili beni uyarmasına öfkelenmem & 96,36 & 85,16 & $-1,558$ & 0,11 \\
\hline Çok yoğun olsam bile müşterinin istek ve ihtiyaçlarını karşılamaya çaba sarf ederim & 100,38 & 79,92 & $-2,996$ & 0,00 \\
\hline $\begin{array}{l}\text { Çalışma hayatımda problemlerle karşılaştığımda genellikle soğukkanlılığımı } \\
\text { koruyabilirim }\end{array}$ & 96,72 & 84,69 & $-1,686$ & 0,09 \\
\hline Çalıştığım bölümde her zaman düşünerek hareket ederim & 96,93 & 84,42 & $-1,920$ & 0,05 \\
\hline Çalışma hayatımda problemleri çözerken genellikle zorlanmam & 91,10 & 92,03 &,- 132 & 0,89 \\
\hline S1k sık birim/görev değişikliği beni sinirlendirmez & 95,50 & 86,29 & $-1,196$ & 0,23 \\
\hline Çalışma arkadaşlarıma işleri öğretirken tekrar tekrar anlatmak beni sıkmaz. & 97,71 & 83,41 & $-1,953$ & 0,05 \\
\hline Yapacak işim çok fakat zamanımın az olduğu durumlarda bile sakince davranabilirim & 95,67 & 86,06 & $-1,315$ & 0,18 \\
\hline $\begin{array}{l}\text { Müdürüm/şefim konuşurken, konuşmasını bitirmeden araya girer söylemek istediğimi } \\
\text { söylerim* }\end{array}$ & 100,10 & 80,29 & $-2,674$ & 0,00 \\
\hline Çalıştığım alandaki mekanik veya elektronik cihazların bozulması beni kızdırmaz & 94,63 & 87,42 &,- 936 & 0,34 \\
\hline Hasta veya uykusuz olduğum zamanlarda bile işime gereken önemi vermeye çalışırım & 101,15 & 78,92 & $-3,210$ & 0,00 \\
\hline Çalışırken sürekli saatime bakarım* & 100,98 & 79,15 & $-2,854$ & 0,00 \\
\hline Çok yorgun olsam bile güler yüz ile sorunları çözmeye çalışırım & 96,73 & 84,68 & $-1,746$ & 0,08 \\
\hline Mesaimin bitişinde fazla mesai yapmam istenmesi beni sinirlendirmez & 103,66 & 75,65 & $-3,779$ & 0,00 \\
\hline İş yerinde yaşadığım sıkıntılardan genellikle yakınmam & 103,12 & 76,35 & $-3,594$ & 0,00 \\
\hline $\begin{array}{l}\text { Haksız yere azarlandığımı düşündüğümde bile sakince bu durumun geçmesini } \\
\text { beklerim }\end{array}$ & 101,15 & 78,92 & $-2,897$ & 0,00 \\
\hline Sinirli bir müşteriyle karşılaştığımda çoğunlukla müşteriyi sakinleştirebilirim & 100,77 & 79,41 & $-2,952$ & 0,00 \\
\hline Çalışırken "işler yeter ki bitsin de nasıl biterse bitsin" diye düşünmem & 99,77 & 80,72 & $-2,559$ & 0,01 \\
\hline Çalışırken gün içinde çok sık sinirlenmem & 95,67 & 86,06 & $-1,323$ & 0,18 \\
\hline Birçok işi aynı anda yapıp işleri hemen bitirmeye çalışmam & 102,00 & 77,82 & $-3,241$ & 0,00 \\
\hline Yöneticilerimin bana olan sert tavrına karşılık vermem & 98,75 & 82,05 & $-2,210$ & 0,02 \\
\hline Sorumluluklarını yerine getirmeyen çalışma arkadaşlarımı sürekli uyarırım & 94,29 & 87,86 &,- 883 & 0,37 \\
\hline Çoğu zaman işyerinde yaşadığım sıkıntılardan şikâyet etmem & 102,88 & 76,66 & $-3,503$ & 0,00 \\
\hline Genelde sakin bir insanımdır & 93,30 & 89,15 &,- 572 & 0,56 \\
\hline Uzun bir yazıyı baştan sona sabırla okuyabilirim & 88,70 & 95,15 &,- 851 & 0,39 \\
\hline Problem çıkaran müşterilere tahammül edebilirim & 99,59 & 80,95 & $-2,545$ & 0,01 \\
\hline Görevim haricinde bir iş yapmam gerektiğinde sinirlenmem & 98,02 & 82,99 & $-1,978$ & 0,04 \\
\hline Yapılması mümkün olmayan müşteri talepleri beni sinirlendirmez & 83,82 & 101,52 & $-2,310$ & 0,02 \\
\hline Problem yaşadığım iş arkadaşlarıma tahammül edebilirim & 94,57 & 87,50 &,- 956 & 0,33 \\
\hline Otelin yoğun olduğu zamanlarda telaşlanmam & 98,68 & 82,13 & $-2,315$ & 0,02 \\
\hline $\begin{array}{l}\text { Müşterinin herhangi bir konuda problemi olduğunda telaşlanmadan sorunu çözmeye } \\
\text { çalışırım }\end{array}$ & 98,72 & 82,08 & $-2,538$ & 0,01 \\
\hline
\end{tabular}


Tablo 9'a göre araştırma kapsamında yer alan 40 sorudan 21'inde anlamlı farklılıkların olduğu görülmektedir $(\mathrm{p}<0,05)$. Bu ifadeler aşağıda gösterilmiştir. "Konuk şikâyetleriyle baş etmede zorluk yaşamam", "Görev aldığım birimde yaşadığım sıkıntılara katlanırım", "Kibarca uyarmama rağmen gürültü ve tatsızlık çıaran konuğa sakince yaklaşırım”, "Çok yoğun olsam bile müşterinin istek ve ihtiyaçlarını karşılamaya çaba sarf ederim", "Müdürüm/şefim konuşurken, konuşmasını bitirmeden araya girer söylemek istediğimi söylerim", "Hasta veya uykusuz olduğum zamanlarda bile işime gereken önemi vermeye çalışırım", "Çalışırken sürekli saatime bakarım.", “Mesaimin bitişinde fazla mesai yapmam istenmesi beni sinirlendirmez", "İş yerinde yaşadığım sıkıntılardan genellikle yakınmam", "Haksız yere azarlandığımı düşündüğümde bile sakince bu durumun geçmesini beklerim", "Sinirli bir müşteriyle karşılaştığımda çoğunlukla müşteriyi sakinleştirebilirim", "Çalışırken "işler yeter ki bitsin de nasıl biterse bitsin" diye düşünmem", "Birçok işi aynı anda yapıp işleri hemen bitirmeye çalışmam", "Yöneticilerimin bana olan sert tavrına karşıllık vermem", "Çoğu zaman işyerinde yaşadığım sıkıntılardan şikâyet etmem", "Problem çıaran müşterilere tahammül edebilirim", "Görevim haricinde bir iş yapmam gerektiğinde sinirlenmem", "Otelin yoğun olduğu zamanlarda telaşlanmam", "Müşterinin herhangi bir konuda problemi olduğunda telaşlanmadan sorunu çözmeye çalışırım" ifadelerinde evli katılımcılar bekâr katılımcılara göre farklı görüş belirtmişlerdir.

Diğer taraftan, "Çalışma hayatımda genellikle çok konuşmayı severim", "Yapılması mümkün olmayan müşteri talepleri beni sinirlendirmez" ifadelerinde bekâr katılımcılar evli katılımcılara göre farklı görüş belirtmişlerdir.

\section{Bölüm Değişkenine İlişkin Bulgular}

Katılımcıların çalıştıkları bölüm ile sabır düzeyleri arasında istatiksel olarak anlamlı bir farklılığın olup olmadığını aramak amacıyla uygulanan Mann- Whitney U Testi'nden elde edilen bulgular Tablo 10'da gösterilmiştir.

Tablo 10. Katılımcıların Sabır Düzeylerinin Bölüm Değişkenine Göre Farklılık Gösterip Göstermediğine İlişkin Mann Whitney U Testi Bulguları

\begin{tabular}{|c|c|c|c|c|c|}
\hline \multirow{3}{*}{ İfadeler } & \multicolumn{2}{|c|}{ Grup sira ortalaması } & Mann-Whitney U Testi & Z & P \\
\cline { 2 - 3 } \cline { 5 - 6 } & Ön büro & Yiyecek-içecek & & $-1,102$ & 0,270 \\
\cline { 2 - 3 } & 96,15 & 87,52 & 3725,500 & & \\
\hline
\end{tabular}

Buna göre katılımcıların çalıştıkları bölüm ile sabır düzeyleri arasında istatiksel olarak anlamlı bir farklılığın olmadığı tespit edilmiştir ( $>>0,05)$. Sonuç olarak "Ön büro/servis elemanlarının sabır düzeyleri ile çalıştıkları bölüm arasında bir farklılık vardır" (H6) hipotezi reddedilmiştir.

\section{Sektörde Çalışma Süresi Değişkenine İlişkin Bulgular}

Katılımcıların sektörde çalışma süreleri ile sabır düzeyleri arasında istatiksel olarak anlamlı bir farklılığın olup olmadığını aramak amacıyla uygulanan Kruskal Wallis Testi'nden elde edilen bulgular Tablo 13'te gösterilmiştir. 
Tablo 11. Katılımcıların Sabır Düzeylerinin Sektörde Çalışma Süresi Değişkenine Göre Farklılık Gösterip Göstermediğine İlişkin Kruskal Wallis Testi Bulguları

\begin{tabular}{|c|c|c|c|c|c|c|}
\hline \multirow{3}{*}{ İfadeler } & \multicolumn{4}{|c|}{ Grup sira ortalamas1 } & Ki-kare & P \\
\cline { 2 - 7 } & 1 yıldan az & $1-5$ y1l & $6-10$ yıl & 11 yıl ve üzeri & \multirow{2}{*}{11,691} & $\mathbf{0 , 0 0 9}$ \\
\cline { 2 - 5 } & 74,73 & 83,19 & 101,99 & 116,00 & & \\
\hline
\end{tabular}

Buna göre katılımcıların sektörde çalışma süreleri ile sabır düzeyleri arasında istatiksel olarak anlamlı bir farklılığın olduğu tespit edilmiştir $(p<0,05)$. Sonuç olarak “Ön büro/servis elemanlarının sabır düzeyleri ile sektörde çalışma süreleri arasında bir farklılık vardır" (H7) hipotezi kabul edilmiş olup farklılıkların hangi ifadelerde gerçekleştiğini görmek amacıyla her bir ifade için ayrı ayrı Kruskal Wallis Testi uygulanmış ve elde edilen sonuçlar Tablo 12'de gösterilmiştir.

Tablo 12. Katılımcıların Sektörde Çalışma Süresi İle Sabır Düzeylerinin İfadelere Göre Karşılaştırılmasına İlişkin Kruskal Wallis Testi Sonuçları

\begin{tabular}{|c|c|c|c|c|c|c|}
\hline \multirow[t]{2}{*}{ İfadeler } & \multicolumn{4}{|c|}{ Sektörde Çalışma Süresi } & \multirow{2}{*}{$\begin{array}{l}\text { Ki- } \\
\text { kare }\end{array}$} & \multirow[t]{2}{*}{$\mathbf{P}$} \\
\hline & $\begin{array}{c}1 \\
\text { yıldan } \\
\text { az } \\
\end{array}$ & $\begin{array}{l}1-5 \\
\text { yıl }\end{array}$ & $\begin{array}{c}\text { 6-10 } \\
\text { y11 }\end{array}$ & $\begin{array}{c}11 \text { yıl } \\
\text { ve } \\
\text { üzeri }\end{array}$ & & \\
\hline Konuk şikâyetleriyle baş etmede zorluk yaşamam & 82,08 & 86,60 & 96,81 & 107,41 & 5,121 & 0,16 \\
\hline Görev aldığım birimde yaşadığım sıkıntılara katlanırım & 83,15 & 89,23 & 96,24 & 98,22 & 2,280 & 0,51 \\
\hline Çalışma esnasında karşılaştığım zor durumlarla mücadele ederim & 88,48 & 84,33 & 100,25 & 100,39 & 5,395 & 0,14 \\
\hline $\begin{array}{l}\text { Misafirler herhangi bir konuda şikâyetlerini dile getirirken, onları } \\
\text { sonuna kadar dinlerim }\end{array}$ & 87,40 & 89,14 & 93,91 & 98,98 & 1,726 & 0,63 \\
\hline Çalışma hayatımda öfkemi kontrol edebilirim & 76,19 & 87,60 & 98,79 & 106,04 & 6,330 & 0,09 \\
\hline Çalışma hayatımda genellikle çok konuşmayı severim* & 99,31 & 97,86 & 80,76 & 84,54 & 4,537 & 0,20 \\
\hline $\begin{array}{l}\text { Kibarca uyarmama rağmen gürültü ve tatsızlık çıkaran konuğa } \\
\text { sakince yaklaşırım }\end{array}$ & 72,21 & 88,17 & 101,84 & 101,67 & 8,161 & 0,04 \\
\hline $\begin{array}{l}\text { Otel kurallarına uymayan konuklara uymaları gereken kuralları } \\
\text { nezaketle söylerim }\end{array}$ & 77,46 & 94,06 & 92,29 & 96,57 & 3,721 & 0,29 \\
\hline $\begin{array}{l}\text { Terfi edilmeyeceğimi bilsem bile uzun yıllar aynı birimde/görevde } \\
\text { çalışabilirim }\end{array}$ & 87,00 & 88,80 & 88,08 & 113,85 & 5,038 & 0,16 \\
\hline Çalışma arkadaşımın işimle ilgili beni uyarmasına öfkelenmem & 75,15 & 86,67 & 102,07 & 103,09 & 7,666 & 0,05 \\
\hline $\begin{array}{l}\text { Çok yoğun olsam bile müşterinin istek ve ihtiyaçlarını karşılamaya } \\
\text { çaba sarf ederim }\end{array}$ & 75,31 & 83,43 & 105,62 & 106,33 & 13,192 & 0,00 \\
\hline $\begin{array}{l}\text { Çalışma hayatımda problemlerle karşılaştığımda genellikle } \\
\text { soğukkanlılığımı koruyabilirim }\end{array}$ & 79,71 & 85,27 & 99,69 & 108,24 & 7,325 & 0,06 \\
\hline Çalıştığım bölümde her zaman düşünerek hareket ederim & 86,13 & 85,05 & 97,18 & 107,43 & 6,125 & 0,10 \\
\hline Çalışma hayatımda problemleri çözerken genellikle zorlanmam & 80,06 & 93,05 & 90,47 & 101,30 & 2,651 & 0,44 \\
\hline S1k sık birim/görev değişikliği beni sinirlendirmez & 86,29 & 89,81 & 90,28 & 106,09 & 2,232 & 0,52 \\
\hline $\begin{array}{l}\text { Çalışma arkadaşlarıma işleri öğretirken tekrar tekrar anlatmak beni } \\
\text { sıkmaz }\end{array}$ & 80,08 & 84,69 & 106,06 & 95,48 & 7,730 & 0,05 \\
\hline $\begin{array}{l}\text { Yapacak işim çok fakat zamanımın az olduğu durumlarda bile } \\
\text { sakince davranabilirim }\end{array}$ & 93,31 & 86,94 & 96,72 & 93,70 & 1,382 & 0,71 \\
\hline $\begin{array}{l}\text { Müdürüm/şefim konuşurken, konuşmasını bitirmeden araya girer } \\
\text { söylemek istediğimi söylerim * }\end{array}$ & 89,29 & 81,87 & 101,58 & 105,13 & 7,010 & 0,07 \\
\hline $\begin{array}{l}\text { Çalıştığım alandaki mekanik veya elektronik cihazların bozulması } \\
\text { beni kızdırmaz }\end{array}$ & 86,63 & 91,01 & 93,24 & 94,80 & ,394 & 0,94 \\
\hline $\begin{array}{l}\text { Hasta veya uykusuz olduğum zamanlarda bile işime gereken } \\
\text { önemi vermeye çalışırım. }\end{array}$ & 79,71 & 84,53 & 103,96 & 101,20 & 8,302 & 0,04 \\
\hline Çalışırken sürekli saatime bakarım* & 81,50 & 79,97 & 112,38 & 96,20 & 13,971 & 0,00 \\
\hline Çok yorgun olsam bile güler yüz ile sorunları çözmeye çalışırım & 86,87 & 84,32 & 104,67 & 92,24 & 6,461 & 0,09 \\
\hline $\begin{array}{l}\text { Mesaimin bitişinde fazla mesai yapmam istenmesi beni } \\
\text { sinirlendirmez }\end{array}$ & 76,96 & 86,67 & 99,47 & 106,91 & 6,575 & 0,08 \\
\hline
\end{tabular}




\begin{tabular}{|c|c|c|c|c|c|c|}
\hline İş yerinde yaşadığım sıkıntılardan genellikle yakınmam & 65,54 & 85,84 & 100,70 & 119,98 & 17,418 & 0,00 \\
\hline $\begin{array}{l}\text { Haksız yere azarlandığımı düşündüğümde bile sakince bu } \\
\text { durumun geçmesini beklerim }\end{array}$ & 68,40 & 85,73 & 107,25 & 102,33 & 12,213 & 0,00 \\
\hline $\begin{array}{l}\text { Sinirli bir müşteriyle karşılaştığımda çoğunlukla müşteriyi } \\
\text { sakinleştirebilirim }\end{array}$ & 74,90 & 84,33 & 105,75 & 103,28 & 10,711 & 0,01 \\
\hline $\begin{array}{l}\text { Çalışırken "işler yeter ki bitsin de nasıl biterse bitsin" } \\
\text { diye düşünmem }\end{array}$ & 92,21 & 82,00 & 103,62 & 96,76 & 6,288 & 0,09 \\
\hline Çalışırken gün içinde çok sık sinirlenmem & 89,15 & 86,33 & 89,96 & 115,83 & 6,804 & 0,07 \\
\hline Birçok işi aynı anda yapıp işleri hemen bitirmeye çalışmam & 85,02 & 84,89 & 100,60 & 101,54 & 4,524 & 0,21 \\
\hline Yöneticilerimin bana olan sert tavrına karşılık vermem & 87,40 & 80,41 & 107,67 & 98,63 & 9,866 & 0,02 \\
\hline $\begin{array}{l}\text { Sorumluluklarını yerine getirmeyen çalışma arkadaşlarımı sürekli } \\
\text { uyarırım }\end{array}$ & 77,13 & 91,68 & 99,80 & 88,35 & 3,867 & 0,27 \\
\hline Çoğu zaman işyerinde yaşadığım sıkıntılardan şikâyet etmem & 78,17 & 83,87 & 101,06 & 111,83 & 9,411 & 0,02 \\
\hline Genelde sakin bir insanımdır & 92,48 & 87,96 & 82,68 & 122,78 & 11,738 & 0,00 \\
\hline Uzun bir yazıyı baştan sona sabırla okuyabilirim & 88,48 & 89,99 & 89,09 & 105,70 & 2,086 & 0,55 \\
\hline Problem çıkaran müşterilere tahammül edebilirim & 76,04 & 87,07 & 96,30 & 113,72 & 8,482 & 0,03 \\
\hline Görevim haricinde bir iş yapmam gerektiğinde sinirlenmem & 92,92 & 83,78 & 92,97 & 113,74 & 6,338 & 0,09 \\
\hline Yapılması mümkün olmayan müşteri talepleri beni sinirlendirmez & 100,90 & 90,64 & 82,16 & 105,00 & 4,222 & 0,23 \\
\hline Problem yaşadığım iş arkadaşlarıma tahammül edebilirim & 84,90 & 87,64 & 101,14 & 90,74 & 2,939 & 0,40 \\
\hline Otelin yoğun olduğu zamanlarda telaşlanmam & 70,62 & 88,83 & 104,31 & 95,57 & 9,116 & 0,02 \\
\hline 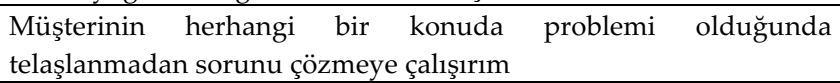 & 75,21 & 89,42 & 99,62 & 98,89 & 6,203 & 0,10 \\
\hline
\end{tabular}

Tablo 12 incelendiğinde, araştırma kapsamında yer alan 40 sorudan 12'inde anlamlı farklılıkların olduğu görülmektedir $(\mathrm{p}<0,05)$. Bu ifadeler aşağıda gösterilmiştir.

"Kibarca uyarmama rağmen gürültü ve tatsızlık çıkaran konuğa sakince yaklaşırım", "Çok yoğun olsam bile müşterinin istek ve ihtiyaçlarını karşılamaya çaba sarf ederim", "Hasta veya uykusuz olduğum zamanlarda bile işime gereken önemi vermeye çalışırım”, "Çalışırken sürekli saatime bakarım", "İş yerinde yaşadığım sıkıntılardan genellikle yakınmam", "Haksız yere azarlandığımı düşündüğümde bile sakince bu durumun geçmesini beklerim", "Sinirli bir müşteriyle karşılaştığımda çoğunlukla müşteriyi sakinleştirebilirim", "Yöneticilerimin bana olan sert tavrına karşılık vermem", "Çoğu zaman işyerinde yaşadığım sıkıntılardan şikâyet etmem", "Problem çıkaran müşterilere tahammül edebilirim", "Otelin yoğun olduğu zamanlarda telaşlanmam" ifadelerine 11 yıl ve üzeri ve 6-10 yıl arası sektörde çalışan katılımcılar daha yüksek katılım göstermiştir. Bir diğer ifade ile 1 yıldan az ve 1-5 yıl arası sektörde çalışan katılımcılar daha düşük katılım göstermiştir. Son olarak "Genelde sakin bir insanımdır" ifadesine ise 11 yıl ve üzeri sektörde çalışan katılımcılar daha yüksek katılım göstermiştir.

\section{SONUÇ ve TARTIŞMA}

Bu araştırmada Kahramanmaraş'ta faaliyet gösteren turizm belgeli konaklama işletmelerinde istihdam edilen ön büro ve servis personelinin sabır düzeyinin belirlenmesi ve sabır düzeyinin demografik ve mesleki değişkenlere göre farklllık gösterip göstermediği ortaya konulmaya çalışılmıştır. Katılımcıların sabır tutumlarını ölçmek için hazırlanan anket formu Schnitker (2012)'in Sabır Ölçeği ile Erken (2009)'in Sabırlı Davranış Ölçeği' nden yararlanılarak hazırlanmıştır. Toplam 182 çalışana uygulanan anketlerden elde edilen verilere istatistiksel analizler uygulanmış ve elde edilen bulgular yorumlanmıştır.

Bu araştırmada ulaşılan temel sonuç, ön büro ve servis elemanlarının sabır düzeylerinin yüksek olduğu yani sabırlı oldukları yönündedir. Turizm, insanları memnun etme odaklı olduğundan çalışan personelin böyle bir sektörde çalışabilmesi için sabırlı kişilik özelliği taşıması beklenmektedir. Literatürde bulunan bazı çalışmalarda turizm personelinde ve turizm mesleğini seçecek öğrencilerde sabır özelliği bulunması belirtilmiştir (Tetik, 2006; Demirtaş, 2010a; 
Demirtaş, 2010b; Kaya ve Özhan, 2012; Polat Üzümcü, 2015; Eker ve Zengin, 2016; Pelit, Soybalı ve Ak, 2017; Özkan, 2017; Tan, 2017). Araştırmaya katılan ön büro ve servis personellerinin sabır düzeyinin yüksek olması bu bilgiyle örtüşmektedir. Bununla birlikte Yilmaz (2018)'ın bir otelde konaklayan misafirler üzerinde yaptığı bir araştırmada, konaklama ve check-out işlemleri sırasında olumlu algılanan olayların sabır, dikkat, misafirperverlik, nezaket ve hız gibi çalışan davranışlarıyla ilgili olaylar olduğu tespit edilmiştir. Ayrıca Grandey, Fisk ve Mattila (2005), çalışanlarda sabırlı ve içten davranışların müşteri memnuniyetini artırdığını iddia etmişlerdir. Kuo (2007) ise müşterilerin şikayetlerini veya memnuniyetsizliklerini çözmek için çalışanların sabırlı ve çalışkan olmaları gerektiğini belirtmektedir. Pelit, Soybalı ve Ak (2017), Afyonkarahisar'da bulunan termal otel işletmelerinde yaptıkları bir araştırmada personel seçiminde sabır unsuruna dikkat edilmesi gerektiğini belirtmişlerdir. Bu işletmelerin müşteri profilinin genellikle daha çok anlayış, hoşgörü, sabır ve ilgi isteyen yaşlılar ve hastalardan oluşması nedeniyle işe alım sürecinde adayların bu tür özelliklerini tespit etmeye yönelik testlerin kullanılmasını önermişlerdir. Fakat Pelit, Türkmen ve Yarmacı (2010)'nın Ankara ve Aydın'da bulunan otel çalışanlarının kişilik özelliklerini değerlendirdikleri bir araştırmada işgörenlerin, A tipi kişilik özelliklerine daha yatkın olduğu sonucuna varılmıştır. A tipi kişilik özelliğine sahip insanlar agresif, sabırsız, aceleci kişilerdir (Pelit, Türkmen ve Yarmacl, 2010: 11). Araştırmamızın sonucunun Ankara ve Aydın örneğinden farklı olmasının nedeni ise işletme türünden kaynaklandığı düşünülmektedir. Pelit, Soybalı ve Ak (2017)'ın belirttiği gibi özellikle termal turizm tesislerinde çalışan personellerde sabır özelliği bulunmalıdır. Kahramanmaraş termal turizm yönünden zengin bir şehirdir (https://kahramanmaras.ktb.gov.tr/). Araştırma verilerinin genellikle termal turizm tesislerinden toplanması çalışanların sabır düzeyinin yüksek çıkmasına neden olmuş olabilir. Termal turizm tesislerinde çalışan bireylerin sabırlı kişiler olduğu düşünülmektedir.

Turizm çalışanlarının sabır tutumunu ölçen ampirik bir çalışmaya ulaşılamamıştır. Hizmet sektöründe çalışabilmek için sabrın gerekli bir beceri olduğu kanısından yola çıkılarak hizmet verme yatkınlığı ile ilgili araştırmaların sonuçları incelenmiştir. Bu araştırmaların sonuçları ile araştırmamızın sonucu benzerlik göstermektedir. Yapılan araştırmalarda turizm çalışanlarının hizmet verme yatkınlığının yüksek düzeyde olduğu tespit edilmiştir (Başoda, 2012; Baş, 2015; Başoda, 2016; Çullu Kaygisız ve Eren, 2017; Eren ve Demirel, 2017, Bibican, 2019; Kale, 2019). Bu araştırmada otel çalışanlarının sabır düzeyinin yüksek olduğu saptanmıştır. Turizm çalışanları açısından düşünüldügünde psikolojik sermaye düzeyi (umut, özyeterlilik, dayanıklılık, iyimserlik) de sabır düzeyine yakın bir konu olarak değerlendirilebilir. Yapılan araştırmalarda otel çalışanlarının psikolojik sermaye düzeylerinin yüksek olduğu ortaya çıkmıştır (Örgün, Keskin ve Erol, 2017; Kumlu ve Güçlü Nergiz, 2018; Yorulmaz ve Yavan, 2018; Özdemir, 2019; Suna ve Okun, 2019).

Sosyal bilimlerde her araştırmada olduğu gibi bu araştırma da bazı sınırlılıklara sahiptir. Zaman ve maliyet konusundaki kısıtlar nedeniyle çalışma Kahramanmaraş'ta gerçekleştirilmiştir. Çalışma araştırmaya katılan katılımcıların görüşleri ile sınırlıdır. Araştırmanın diğer bir sınırlılığ ise; araştırma verilerinin yalnızca konaklama işletmesi çalışanlarından elde edilmesidir. Seyahat işletmeleri bu araştırma kapsamına dahil edilmemiştir. Araştırma konaklama işletmelerinde müşteri ile en çok diyalog halinde olan ön büro ve yiyecek-içecek departmanları ile sınırlandırılmıştır. Diğer departmanlar (kat hizmetleri, teknik servis, güvenlik vs.) araştırmaya dahil edilmemiştir. Bu araştırmadan elde edilen sonuçlar doğrultusunda, araştırmacılara birtakım öneriler sunulmaktadır.

Literatürde turizm çalışanlarının sabır tutumunu inceleyen bir araştırmaya rastlanmamıştır. Bu durum araştırmanın sonuçlarını karşılaştırmayı oldukça zorlaştırmıştır. Bundan dolayı benzer çalışmaların Türkiye'de faaliyet gösteren turizm işletmeleri üzerinde yapılarak sayısının 
arttırılmasının hem genelleme yapılabilmesi hem de sonuçlar arası karşılaştırmalar yapılabilmesi açısından önemli olduğu düşünülmektedir. Bu bağlamda farklı şehirlerdeki otel işletmelerinde çalışan bireylerin sabır düzeyleri araştırılabilir. Konaklama ve seyahat işletmeleri bünyesinde çalışan bireylerin sabır düzeylerinin belirlenmesi ile bu işletmeler arasında karşılaştırma yapılabilir. Bununla birlikte turizm dışındaki farklı sektörlerde çalışan kişilerin sabır tutumunun belirlendiği nitel veya nicel çalışmalar yapılabilir. Öte yandan turizm çalışanlarının sabır düzeyleri ile psikolojik iyi oluş, iş-yaşam doyumu, örgütsel stres, işten ayrılma niyeti, örgütsel bağlılık, örgütsel güven, iş tatmini, iş performansı, yaşam kalitesi, mutluluk düzeyi, özsayg1 düzeyi, kariyer tutumu, tükenmişlik düzeyi, başa çıkma düzeyi, depresyon düzeyi veya öfke düzeyleri arasındaki ilişkileri inceleyen çalışmaların yapılmasının literatüre katkı sunabileceği düşünülmektedir.

\section{KAYNAKÇA}

Akyol, B. (2019). Engelli Bakımı Ön Lisans Öğrencilerinin Sabır Düzeyleri İle Kişilik Özellikleri Arasındaki İlişkinin İncelenmesi, Yayınlanmamış Yüksek Lisans Tezi, Necmettin Erbakan Üniversitesi, Konya.

Ateş, N. E. ve Kayıklık, H. (2019). Şehit Ailelerinde, Gazilerde ve Gazi Ailelerinde Sabır ve Dinî Başa Çıkma İlişkisi, Çukurova Üniversitesi İlahiyat Fakültesi Dergisi, 19(1): 225-236.

Azizi Ziabari, L. S., Valikhani, A., Amlashi, M. A. and Ireland, M. (2019). Patience Mediates the Relationship Between Mindfulness and Pain in Patients with Cardiovascular Diseases, Mental Health, Religion \& Culture, 22(3): 319-329.

Başoda, A. (2012). Kişilik Özelliği Olarak Hizmet Verme Yatkınlığının İş Tatmini Ve İşten Ayrılma Niyeti Üzerindeki Etkisi: Konaklama İşletmelerinde Bir Uygulama, Yayınlanmamış Yüksek Lisans Tezi, Nevşehir Üniversitesi, Nevşehir.

Baş, M. (2015). Kış Turizminde Faaliyet Gösteren İşletme Çalışanlarının Hizmet Verme Yatkınlı̆̆ının Tespiti: Bir Araştırma, Yayınlanmamış Yüksek Lisans Tezi, Süleyman Demirel Üniversitesi, Isparta.

Başoda, A. (2016). Otel Çalışanlarının Hizmet Verme Yatkınlığının İş Tatmini Üzerindeki Etkisi, Sosyal Bilimler Meslek Yüksekokulu Dergisi, 19(41): 75-85.

Bibican, Ç. (2019). Ankara'da Bulunan Beş Yıldızlı Otel İsletmelerinde Hizmet Verme Yatkınlı̆̆ının Örgütsel Bağlılık Ve İş Tatmini İlişkisi Üzerindeki Aracı Etkisi, Yayınlanmamış Yüksek Lisans Tezi, Atılım Üniversitesi, Ankara.

Çullu Kaygısız, N. ve Eren, D. (2017). Otel İşletmelerinde İçsel Pazarlama Uygulamalarının İşgörenlerin Hizmet Verme Yatkınlığı ve Olumlu Sosyal Davranışları Üzerine Etkisi: Nevşehir Örneği, Seyahat ve Otel İsletmeciliği Dergisi, 14(3): 74-87.

Demirtaş, N. (2010a). Ön Büro İşlemleri. (1. Basım), Ankara: Ankara Üniversitesi Uzaktan Eğitim Yayınları.

Demirtaş, N. (2010b). Ön Büro Yönetimi. (1. Basım), Ankara: Ankara Üniversitesi Uzaktan Eğitim Yayınları.

Doğan, M. (2014). Dindarlık Sabır ve Psikolojik İyi Olma Arasındaki İlişkiler, Yayınlanmamış Doktora Tezi, Atatürk Üniversitesi, Erzurum.

Doğan, M. (2017). Karakter Gücü Olarak Sabır ve Psikolojik İyi Oluş İlişkisi, The Journal of Happiness \& Well-Being, 5(1): 134-153. 
Doğan, M. ve Gülmez, Ç. (2014). Sabır Ölçeğinin Türkçeye Uyarlanması: Geçerlik ve Güvenirlik Çalışması, Atatürk Üniversitesi İlahiyat Fakültesi Dergisi, (42): 263-279.

Doğan, M. (2016). Engelli Çocuğa Sahip Ebeveynler İle Sağlıklı Çocuk Sahibi Ebeveynlerin Dinî Başa Çıkma, Umut ve Sabır Düzeylerinin Karşılaştırılması, İnsan ve Toplum Bilimleri Araştırmaları Dergisi, 5(8): 3214-3245.

Dudley, K. C. (2003). Empirical Development of a Scale of Patience, Dissertation Doctor of Philosophy in Counseling Psychology, University of West Virginia, Morgantown, West Virginia.

Ege, R. (2013). Anlam Alanı İçin Sabrı Bir Tutum Olarak Yeniden Düşüncesi, Dini Araştırmalar Dergisi, 16(43): 67- 86.

Eker, N. ve Zengin, B. (2016). Turist Rehberliği Eğitiminin Değerlendirilmesi: Profesyonel Turist Rehberleri Üzerine Bir Uygulama, Eğitim ve Öğretim Araştırmaları Dergisi, 5(4): 65-74.

Eliöz, M., Çebi, M., İmamoğlu, O., İslamoğlu, İ. ve Yamak, B. (2019). Üniversite Öğrencilerinin Sabır ve Saldırganlık Düzeyleri, Uluslararası Sosyal Araştırmalar Dergisi, 12(65): 775-779.

Eliüşük, A. (2014). Sabır Eğiliminin Öz Belirleme Öz Anlayıs ve Kişilik Özellikleri Açısından İncelenmesi, Yayınlanmamış Doktora Tezi, Necmettin Erbakan Üniversitesi, Konya.

Eliüşük, B. A. and Izgar, G. (2018). Effects of the Patience Training Program on Patience and WellBeing Levels of University Students, Journal of Education and Training Studies, 6(1): 159-168.

Elshaer, A. M. and Marzouk, A. M. (2020). Labor in the Tourism and Hospitality Industry (Skills, Ethics, Issues and Rights). Canada: Apple Academic Press Taylor \& Francis Group.

Eren, D. ve Demirel, N. (2017). Nevşehir Bölgesi'ndeki Turist Rehberlerinin Hizmet Verme Yatkınlığı Düzeylerinin Ölçülmesi, Disiplinler arası Akademik Turizm Dergisi, 2(1): 5-22.

Erken, M. (2009). Empati Becerisinin Ahlaki Davranışlar Üzerindeki Etkisi, Yayınlanmamış Yüksek Lisans Tezi, Sakarya Üniversitesi, Sakarya.

Ermiş, E. ve İmamoğlu, O. (2019). Değişik Fakültelerdeki Öğrencilerin Sabır Eğilimlerinin Araştırılması, Uluslararası Toplum Araştırmaları Dergisi, 13(19): 263- 280.

Gençdoğan, B., Gülbahçe, A. ve Gülbahçe, Ö. (2015). Hoşgörü ve Sabır ile Yaşam Kalitesi Arasındaki İlişki, (Editör) Kaymakcan, R., Tınaz, N., Altın, Z. Ş., Zengin, M., Okudan, A. Y. Yiğit, H.: Değerler ve Eğitimi II içinde (ss.525-536) Ankara: Ertem Basım.

Grandey, A. A., Fisk, G. M., Mattila, A. S., Jansen, K. J., and Sideman, L. A. (2005). Is “Service with A Smile" Enough? Authenticity of Positive Displays During Service Encounters, Organizational Behavior and Human Decision Processes, 96(1): 38-55.

Gül, Y. E. ve Çeliköz, N. (2018). Üniversite Öğrencilerinin Sabır Eğilim Düzeylerinin İncelenmesi, Manas Sosyal Araştırmalar Dergisi, 7(3): 77-87.

Gürbüz, S. ve Şahin, F. (2016). Sosyal Bilimlerde Araştırma Yöntemleri. (3. Basım), Ankara: Seçkin Yayıncilik.

Habeeb, K. T. (2016). A Study of Relationship Between Patience, Confidence and Stress Level Among Adolescents, International Journal of Educational Research Studies, 2(9): 685-689.

Ibn Rasoul Sanaati, N., Hossein Sabet F. and Motamedi A. (2018). Role of Patience with Mediating Self-Differentiation in Emotional Regulation and Perceived Stress among Nurses, Islamic Life Style Centered on Health, 2(4): 211-216. 
Irmak, E. (2019). Ebelerde Sabır Davranışının Empatik Beceriye Etkisi, Yayınlanmamış Yüksek Lisans Tezi, İstanbul Medipol Üniversitesi, İstanbul.

Kahramanmaraş İl Kültür ve Turizm Müdürlügü (2020). https://kahramanmaras.ktb.gov.tr/TR61248/termal-turizm.html> [Erişim Tarihi: 29.03.2020].

Kale, A. (2019). Otel Çalışanlarının Hizmet Verme Yatkınlıklarının İş Tatminlerine Ve İşten Ayrılma Niyetlerine Etkisi: Mersin İli Örneği, Yayınlanmamış Doktora Tezi, Mersin Üniversitesi, Mersin.

Kaya, U. ve Özhan, Ç. K. (2012). Duygusal Emek ve Tükenmişlik İlişkisi: Turist Rehberleri Üzerine Bir Araştırma, Çalışma İlişkileri Dergisi, 3(2): 109-130.

Karakaş, A. C. (2016). Belediye Çalışanlarında Sabır Tutumunun Yaşam Kalitesi Üzerine Etkisi (Sakarya İli Örneği), İnsan ve Toplum Bilimleri Araştırmaları Dergisi, 5(8): 2742-2757.

Karakaş, A. C. (2018). Sabır Tutumunun Sürekli Öfke İfade Tarzlarına ve Öfke Kontrolüne Etkisi, Türkiye İlahiyat Araştırmaları Dergisi, 2(1): 93-111.

Kıral, B. (2019). Akademik Hayatta Sabır Üzerine Nitel Bir Çalışma, Journal of Computer and Education Research, 7(14): 250-283.

Koç, H. ve Arslan, C. (2019). Üniversite Öğrencilerinde Algılanan Sosyal Destek, Benlik Saygısı ve Sabır Arasındaki İlişkiler, Türk Psikolojik Danışma ve Rehberlik Dergisi, 9(54): 821-840.

Kumlu, T. ve Güçlü Nergiz, H. (2018). Otel İşletmesi Çalışanlarının Pozitif Psikolojik Sermaye Düzeyleri İle Örgütsel Vatandaşlık Davranışları Arasındaki İlişki, Uluslararası Turizm ve Sosyal Araştırmalar Dergisi, (3): 1-13.

Kuo, C. M. (2007). The Importance of Hotel Employee Service Attitude and the Satisfaction of International Tourists, The Service Industries Journal, 27(8): 1073-1085.

Oğan, Y. ve Akar Şahingöz, S. (2018). Otel İşletmeleri Çalışanlarının İletişim Becerileri: Artvin Örneği, AÇÜ Uluslararası Sosyal Bilimler Dergisi, 4(1): 77-103.

Okçu, D. ve Pilatin, U. (2018). Ortaokul Öğrencilerinin Sabır Değeri ile İlgili Algılarının Resim Yoluyla Değerlendirilmesi, Batman Üniversitesi İslami İlimler Fakültesi Hakemli Dergisi, 2(1): 102113.

Olcay, A., Giritlioğlu, İ. ve Çıkmaz, E. (2014). Otel İşletmelerinde Çalışan Personelin İletişim Yeterlilik Düzeyi: Gaziantep Bölgesinde Bir Araştırma, İşletme Araştırmaları Dergisi, 6(1): 385-403.

Olcay, A. ve Sürme, M. (2014). Otel İşletmelerinde Müşteri Şikâyetlerini Belirlemeye Yönelik Ampirik Bir Çalışma, Uluslararası Sosyal Araştırmalar Dergisi, 7(35): 836-855.

Oral, O. (2015). Mâturîdî‘de Sabır, Şükür ve Hikmet İlişkisi, Mütefekkir Aksaray Üniversitesi İslami İlimler Fakültesi Dergisi, 2(4): 343-362.

Örgün, E., Keskin, E. ve Erol, G. (2017). Otel Mutfağı Çalışanlarının Psikolojik Sermaye Düzeyleri Üzerine Bir Araştırma, Journal of Recreation and Tourism Research, 4(4): 174-183.

Özdamar, K. (1999). Paket Programlar İle İstatistiksel Veri Analizi 1. (2. Basım), Ankara: Nisan Kitabevi.

Özdemir, H. Ö. (2019). Konaklama İşletmelerinde Çalışan Personelin Psikolojik Sermayeleri ile Demografik Özellikleri Arasındaki İlişkiler, Anadolu Üniversitesi Sosyal Bilimler Dergisi, 19(3): 259274.

Özdemir, N. (2018). Engelli Ailelerinde Problem Çözme ve Sabır Gösterme Davranışları Arasındaki İlişkinin İncelenmesi, Yayınlanmamış Yüksek Lisans Tezi, İstanbul Ticaret Üniversitesi, İstanbul. 
Özkan, Ç. (2017). Algılanan Örgütsel Desteğin, Örgütsel Bağlllı̆̆a Etkisinde Kişilik Özelliklerinin Rolü: Otel İşletmelerinde Bir Araştırma, Yayınlanmamış Doktora Tezi, Çanakkale Onsekiz Mart Üniversitesi, Çanakkale.

Öztürk Y. ve Seyhan K. (2005). Konaklama İşletmelerinde Sunulan Hizmet Kalitesinin Arttırılmasında İş Gören Eğitiminin Yeri ve Önemi, Ticaret ve Turizm Eğitim Fakültesi Dergisi, (1): 121-140.

Öztürk, Y. ve Pekduyurucu, B. (2009). Müşteri İlişkileri Yönetiminde Ön Büro Departmanı, ABMYO Dergisi, 15: 33-44.

Pelit, E. ve Öztürk, Y. (2011). Otel İşletmeleri İş Görenlerinin Davranışsal ve Psikolojik Güçlendirme Algılamalarındaki Farklılıklar, Ekonomik ve Sosyal Araştırmalar Dergisi, 7(1): 1-28.

Pelit, E., Soybalı, H. H. ve Ak, S. (2017). Termal Otel İşletmelerinde Personel Bulma, Seçme ve Personeli İşe Yerleştirme Sürecindeki Uygulamalar ve Sorunlar Üzerine Bir Araştırma: Afyonkarahisar Örneği, Seyahat ve Otel İşletmeciliği Dergisi, 14(3): 53-73.

Pelit, E., Türkmen, F. ve Yarmacl, N. (2010). Turizm Sektöründeki İşgörenlerin Kişilik Özelliklerini Değerlendirmeye Yönelik Bir Araştırma, Sosyal ve Beşeri Bilimler Dergisi, 2(1): 9-16.

Polat Üzümcü, T. (2015). Otel Yöneticilerinin Turizm Eğitimine Yönelik Algıları: Kocaeli İli Otel Yöneticileri Üzerinde Bir Araştırma, Kocaeli Üniversitesi Sosyal Bilimler Dergisi, 30: 123-150.

Qodariah, S. and Puspitasari, N. R. (2016). Correlation between Patience and Coping Strategy of Mothers with Autistic Children, International Journal of Social Science and Humanity, 6(12): 919-922.

Ro, D. B. (2014). Patient Patients? The Virtue of Patience and Severe Mental Illness, Dissertation Doctor of Psychology, Graduate School of Psychology Fuller Theological Seminary, Pasadena.

Schnitker, S. A. (2012). An examination of Patience and Well-Being, The Journal of Positive Psychology, 7(4): 263-280.

Selviden Albayrak, S. (2012). Otel İşletmelerinin Yiyecek- İçecek Departmanındaki Çalışma Koşullarının İsgören Motivasyonuna Etkileri: İstanbul'daki Beş Yıldızl Otel İşletmelerinde Bir Uygulama, Yayınlanmamış Yüksek Lisans Tezi, Trakya Üniversitesi, Edirne.

Seyhan, B. Y. (2015). Başa Çıkma Değeri Açısından Sabır Üzerine Nitel Bir Çalışma, Akademik Bakış Dergisi, (49): 127-146.

Sökmen A. (2005). Yiyecek İ̧̧ecek Hizmetleri Yönetimi ve İşletmeciliği. (1. Basım), Ankara: Detay Yayıncilik.

Suna, B. ve Okun, O. (2019). Otel Çalışanlarının Psikolojik Sermaye Düzeylerinin Yenilikçi Düşünce Yapısına Etkisi: Van İli Örneği, Iğdır Üniversitesi Sosyal Bilimler Dergisi, (19): 491-518.

Susmuş T. (2002). Maliyet Kontrolünün Sağlanmasında Sorumluluk Muhasebesi Sisteminin Rolü ve Zincir Otel İşletmelerinde Uygulanması, Mevzuat Dergisi, 59, 1-14.

Şencan, H. (2005). Sosyal ve Davranışsal Ölçümlerde Güvenilirlik ve Geçerlilik. (1. Basım), Ankara: Seçkin Yayıncılık

Şit, M. (2016). Türkiye'de Turizm Sektörünün İstihdama Katkısı, Akademik Yaklaşımlar Dergisi, 7(1): 101-117.

Tan, M. (2017). Otel İşletmelerinde İşgörenlerin Kişilik Özellikleri İle Sanal Kaytarma Davranışı Arasındaki İlişkinin Analizi, Yayınlanmamış Yüksek Lisans Tezi, Süleyman Demirel Üniversitesi, Isparta. 
Tatar, S. (2013). İzlenim Yönetimi Davranışlarında Kişilik Özelliklerinin Rolü: Konaklama İşletmeleri Çalışanlarına Yönelik Bir araştırma, Yayınlanmamış Yüksek Lisans Tezi, Dokuz Eylül Üniversitesi, İzmir.

Tetik, N. (2006). Türkiye'de Profesyonel Turist Rehberliği ve Müşterilerin Turist Rehberlerinden Beklentilerinin Analizi (Kuşadası Örneği), Yayınlanmamış Yüksek Lisans Tezi, Balıkesir Üniversitesi, Balıkesir.

Türk Dil Kurumu (2019). Sabır Kelimesinin Sözlük Anlamı, http://sozluk.gov.tr/> [Erişim Tarihi: 28.07.2019].

Türkgeldi, E. (2019). Öğretmen Adaylarmın Sahip Olduğu Değerler Manevi İyi Oluş ve Sabır Arasındaki Yordayıcı İlişkiler, Yayınlanmamış Yüksek Lisans Tezi, İstanbul Sabahattin Zaim Üniversitesi, İstanbul.

Ural, A. ve Kılıç, İ. (2013). Bilimsel Araştırma Süreci ve SPSS İle Veri Analizi. (4. Basım), Ankara: Detay Yayıncilık.

Ünüvar, Ş. (2009). Kişilerarası İletişimin Konaklama İşletmelerindeki Önemi ve Beş Yıldızlı Otellerde Bir Uygulama, Sosyal Ekonomik Araştırmalar Dergisi, 9(18): 375-394.

Valikhani, A., Moustafa, A. and Karimi, A. (2017). Examining Patience as A PsychoReligiousconstruct in Iranian Patients with Cardiovascular Diseases: A Pilot Study, Mental Health, Religion \& Culture, 1-9.

Yıldız, A. (2016). Hz. Eyyûb'ün (a.s.) Hastalıklar Karşısındaki Sabrı ve Manevî Hastalıklarımız, Harran Üniversitesi İlahiyat Fakültesi Dergisi, 21(36): 128-142.

Yıldız, Z. (2011). Turizmin Sektörünün Gelişimi ve İstihdam Üzerindeki Etkisi, Süleyman Demirel Üniversitesi Vizyoner Dergisi, 3(5): 54-71.

Yilmaz, Ö. D. (2018). Revisiting Employee - Guest Interactions in Hotels: An Analysis of Critical Incidents, Journal of Tourism, Heritage \& Services Marketing, 4(2): 17-23.

Yorulmaz ve Yavan (2018). Pozitif Psikolojik Sermayenin İşveren Marka Oluşumu Üzerindeki Etkisi: Turizm Sektörü Örneği. Atatürk Üniversitesi Sosyal Bilimler Enstitüsü Dergisi, 22(2): 10071027.

Zünbülova, S. C. (2019). Hisse Senetlerine Bireysel Yatırım Yapan X ve Y Kuşaklarının Sabır Derecesinin Ölçülmesi Borsa İstanbul Örneği, Yayınlanmamış Yüksek Lisans Tezi, T.C. Maltepe Üniversitesi, İstanbul. 